\title{
SAĞLIK KAMU HİZMETINIIN DAYANAĞI OLAN VE SAĞLIK HAKKINI GÜVENCE ALTINA ALAN DÜZENLEMELER İLE İLKELER*
}

\author{
Arş. Gör. Simge DEMİR BAYRAM
}

\section{ÖZET}

Temel insan haklarından biri olan sağlık hakkı sağlıklı bireylerin var olması için çeşitli yöntemlerle korunmaktadır. Bu yöntemler aynı zamanda temel kamu hizmetlerinden biri olan sağlık hizmetinin de dayanağını oluşturmaktadır. Söz konusu yöntemlerin başında uluslararası sözleşmeler, bildirgeler, anayasalar, kanunlar, KHKlar, nizamnameler, yönetmelikler ve ilkeler gelmektedir.

Geçmişten günümüze uluslararası alandaki sözleşmeler ve bildirgeler aracılığıyla sağlık hakkının korunmasına ve sağlık hizmetinin dayanağının oluşturulmasına yönelik düzenlemeler yapılmıştır. Bu düzenlemeler aracıllğıyla sağlık hizmetinin hukuki temelleri oluşturularak, bireylerin sağlık hakkından yararlanması imkânı yaratılmış ve böylece sağlık hakkın korunması ve geliştirilmesi sağlanmıştır.

Uluslararası alanın yanı sıra, sağlık hakkı ve sağlık hizmeti, ulusal alanda da hukuk düzeninde anayasa, kanun, KHK, CBK, nizamname ve yönetmelik gibi tali düzenlemeler aracılığıyla da düzenlenme imkânı bulmuştur.

Yapılan düzenlemelerin yanı sıra, ilkeler aracılığıyla da sağlık hizmeti dayanağa kavuşmuş ve sağlı hakkı güvenceye sahip olmuştur. Söz konusu ilkeler ile sağlık hizmetinin gereği gibi yerine getirilmesi sağlanarak, bireylerin sağlık hakkını kullanmalarına olanak yaratılmıştır.

Anahtar Kelimeler: Sağlık Hakkı, Sağlık Kamu Hizmeti, Uluslararası Sözleşmeler, Bildirgeler, Ulusal Mevzuat, İlkeler

DOI: 10.33432/ybuhukuk.899214 - Geliş Tarihi: 18.03.2021 - Kabul Tarihi: 28.06.2021.

** Yaşar Üniversitesi Hukuk Fakültesi İdare Hukuku Anabilim Dalı, simge.demir@yasar.edu.tr, ORCID: 0000-0001-9425-4148. 


\title{
REGULATIONS AND PRINCIPLES WHICH ARE THE BASIS OF THE HEALTH PUBLIC SERVICE AND PROTECTING THE RIGHT TO HEALTH
}

\begin{abstract}
The right to health, which is one of the most fundamental human rights, is protected by various methods for the existence of healthy individuals. These methods also constitute the basis of health service which is one of the fundamental public services. International conventions, declarations, constitutions, laws, decree-laws, bylaws, regulations, and principles come first among mentioned methods.

From past to present, arrangements have been made to protect the right to health and to establish the basis of health services through the agreements and declarations in the international arena. Through these regulations, the legal foundations of health service have been established, the opportunity for individuals to benefit from their right to health has been created, and thus, the protection and development of the right to health has been ensured.

In addition to the international arena, the right to health and health service have also been regulated in the national arena through secondary regulations such as constitution, law, decree-law, presidential decree, by law and regulation.

Health service has gained a basis and the right to health has been assured through the principles, in addition to the regulations made. In this way, it has been created an opportunity for individuals to use their right to health by ensuring that health service is carried out duly.
\end{abstract}

Keywords: The Right to Health, Health Public Service, International Conventions, Declarations, National Legislation, Principles. 


\section{Gíriş}

Sağlıklı bir toplum yaratmak için toplumun en küçük yapıtaşı olan bireyin de sağlıklı bir yaşam sürdürmesi şarttır. Bireyin sağlıklı bir yaşam sürdürebilmesi için ise sağlı hakkının korunması gerekliliğinin yanı sıra, sağlık hakkının gereğinin yerine getirilmesi amacıyla bizzat idare tarafindan kamu görevlisi hekimlerce yahut idarenin gözetimi ve denetimi altında özel hukuk kişilerince sunulan sağlik hizmetinin hukuki dayanağının olması ve bu dayanak doğrultusunda sağlık hizmetinin sağlanması gerekmektedir. Bu nedenle sağllk hakkının nasıl koruma altına alındığı ve idarenin faaliyetlerinin arasında yer alan temel kamu hizmetlerinden sağllk hizmetinin dayanağının neler olduğu oldukça önemlidir.

Tarihsel süreç içerisinde sağllk hakkının ve sağlık hizmetinin gelişiminin, uluslar arası ve ulusal anlamda ayrı ayrı incelenmesi yerinde olacaktır. Illk olarak uluslar arası alanda, başta AİHS olmak üzere birçok uluslar arası sözleşmenin sağlık hakkını korumak amacıyla maddeler içerdiği çalışmamızda açıklanacaktır. Bu sözleşmelerin yanı sıra, günümüzde üçüncü dünya ülkeleri olarak anılsa da çalışmamızda inceleneceği üzere bu düzeydeki ülkelerin dahi sağlık hakkını korumak ve sağlık hizmetinin hukuki temellerini oluşturmak için çaba harcadığı ve bildirgeler ile bu çabalarını resmileştirdiği görülecektir.

İkinci olarak ulusal alanda sağllk hakkı ve sağlık hizmetinin hangi anayasalarda yer aldığı, hangi anayasalarda sağlık hakkının yaşama hakkı ile birlikte ele alındığı, hangi anayasalarda başlı başına bir hak olarak düzenlendiği konularına açıklık getirilecektir. Anayasalarımızın dışında kanunlarda, KHKlarda, CBKlarda, nizamnamelerde, yönetmeliklerde nasıl düzenlendiği, bu konulardaki eleştiriler, görüşler ve bu düzenlemelerin etkileri çalışmamıza konu edilecektir.

Son olarak hangi ilkelerin sağlık hakkı ve sağlık hizmeti ile ilişkisi olduğu ve bu iliş̧inin nasıl olduğu, ilkelerin içerikleri, ilgili düzenlemelerde nasıl açıklandığı ve bu ilkelerin hukuken koruma sağlama ve dayanak oluşturmadaki rolü her ilke tek tek mercek altına alınarak incelenecektir. 


\section{Sağlık Hakkını Koruyan ve Sağlık Hizmetinin Dayanağı Olan Başlıca Mevzuat}

Çağımızda insan hakları ile temel hak ve özgürlüklerin ayrım yapılmaksızın tüm insanlara eşit bir şekilde uygulanması, bu hakların korunması ve geliştirilmesi bir ortak amaç olmanın dışında çağdaş dünyadaki demokratik ülkeler için de bir zorunluluk durumundadır ${ }^{1}$. Bu amacın gerçekleştirilmesi adına uluslararası kuruluşlar birçok uluslararası belge hazırlayıp uygulamaya geçirmiş ve amaçlarına ilişkin denetimi de sağlamıştır².

Birleşmiş Milletler Teşkilatı ve Avrupa Konseyi'nin aralarında bulunduğu uluslararası kuruluşlara ve bu kuruluşlarca hazırlanan uluslararası belgelere de taraf olan Türkiye, insan haklarının korunması adına çeşitli yükümlülükler üstlenmiştir. Türkiye, aynı zamanda denetim mekanizmalarının uygulanmasını kabul ederek, taraf olduğu uluslararası antlaşma ve sözleşmeleri mevzuatının da bir parçası haline getirmiştir. Türkiye'de bu yükümlülüklerin yerine getirilmesi ve Anayasamızda belirtilen temel hak ve özgürlüklerin de korunup, daha ileri bir seviyeye taşınması amacıyla pek çok yasal ve idari düzenlemeler yapılmıştır³.

Türkiye'de, insan haklarının ve temel hak ve özgürlüklerin korunması adına Avrupa Birliği'ne tam üyelik sürecinde birçok yenilik getirilmiş, iç hukukumuzun uluslararası belgelere uyum sağlamasına ilişkin yasal ve kurumsal düzenlemeler yapılmıştır; ancak bu düzenlemelerin yapılmasının yeterli olmadığını, uygulanmasının da yapılması kadar önemli ve gerekli olduğunu belirtmemiz gerekmektedir ${ }^{4}$.

1 T.C. Başbakanlık Personel ve Prensipler Genel Müdürlüğü, 1999/39 Nolu Genelge, Sa. B.02.0.PPG.0.12-320-08689, Y.T.25.06.1999, s. 103; T.C. Başbakanlık Personel ve Prensipler Genel Müdürlüğ̈̈, 1997/73 Nolu Genelge, Sa. B.02.0.PRG.0.12-383-27961, Y.T.03.12.1997, s. 1.

2 1999/39 Nolu Genelge, s. 103; 1997/73 Nolu Genelge, s. 1.

3 1997/73 Nolu Genelge, s. 1.

4 T.C. Adalet Bakanlığı Ceza İşleri Genel Müdürlüğü, 158 Nolu Genelge, Sa. 19120602-01006-02-0114-2015-403, Y.T.20.02.2015, s. 1. 


\section{A. Uluslararası Mevzuat}

Sağlık hakkının uluslararası hukukta belirgin bir kategori haline gelmesi, II. Dünya Savaşı sonrasında insan hakları kavramının yerleşmesi ile söz konusu olur $^{5}$. Uluslararası mevzuatın başında ise 1978 yılından günümüze kadar çıkarılan uluslararası sağlık bildirgeleri gelmektedir. Kronolojik olarak incelemek gerekirse:

\section{Dünya Sağlık Örgütü Anayasası/Anatüzüğü}

1946’da Dünya Sağlık Örgütü (DSÖ)'nün kurulması ile çıkarılan DSÖ Anayasası, DSÖ’ye üye devletlerdeki tüm milletlerin mutluluğu ile güvenliğini düzenleyen hükümler içermektedir. Anayasa'da sağlık, hasta veya sakat olmama, fiziksel, sosyal ve ruhsal açıdan iyi olma şeklinde tanımlanmıştır. Sağlık hakkına ayrım gözetilmeksizin tüm insanların erişebilmesi, sağlık hizmetinin en yüksek kalitede olması gerektiği belirtilmiştir. Anayasa'da tüm milletlerin sağlığının önemli olduğu ve bunun için devletlerin işbirliğinin gerektiği, bir devlette sağlığın korunmasına ilişkin elde edilen gelişmenin tüm devletleri etkileyeceği, bir devlette bulaşıcı hastalıklarla ilgili bir gelişme olması durumunda tüm devletlerin tehlikede olacağı, çocuğun sağlıklı gelişmesinin önemi, sağlığa tam anlamıyla ulaşılabilmesi için bilgilerin tüm milletlere verilmesi gerektiği, sağlığın geliştirilmesi adına halkın aydınlatılması gerektiği, hükümetlerin sağlığın korunması ve geliştirilmesi açısından sorumlu olduğu konuları hüküm altına alınmıştır'.

\section{Evrensel İnsan Hakları Bildirgesi}

1948'de Birleşmiş Milletler Genel Kurulu tarafından kabul edilen Evrensel İnsan Hakları Bildirgesi, sağlık hakkına ilişkin hükümler içermektedir. 25. Maddesinde, sağlık hakkı ayrı bir hak olarak sayılmamış, hazırlık evresinde sağlık hakkı temelinde düzenlenen madde son halinde "yeterli bir yaşam

Temiz, Özgür (2014) “Türk Hukukunda Bir Temel Hak Olarak Sağlik Hakkı” Ankara Üniversitesi SBF, C. 69, Sa. 1, ss. 165-188, s. 166.

6 Demir, Mehmet (2006) Sağlık ve Tıp Hukuku Mevzuatı ve Uluslararası Kaynaklar, 1. Baskı, Ankara, Turhan, s. 1347; Temiz, Özgür (2013) “Türk Hukukunda Sağlık Hakkı ve Bir Kamu Hizmeti Olarak Sağlik” (Doktora), Ankara Üniversitesi Sosyal Bilimler Enstitüsü, s. 71-72; Temiz (2014), s.167. 
standardının olması için gereken bileşenlerden biri” şeklinde açıklanmıştır Son hali ile de bu madde, sağlık hakkı için önem teşkil eden bir özellik göstermektedir. Kaldı ki DSÖ’nün sağlık hakkına dair açıkladığımız hükmü ile birlikte ele alındığında bu maddenin sağlık hakkının temel insan haklarından biri olarak nitelendirilmesindeki etkisi göz ardı edilememektedir. Yayınlandığı dönemde hukuken bağlayıcı olmasa da geçen süre içerisinde fiili bağlayıcılık kazanan Evrensel İnsan Hakları Bildirgesi, modern insan hakları hukukunun kurucu belgesi niteliğini kazanması ${ }^{8}$ nedeniyle de önem taşımaktadır.

Evrensel İnsan Hakları Bildirgesi'nin 25. maddesinde sağlığın yanında, beslenme, giyim, konut gibi diğer haklar da düzenlenerek aralarındaki bağ hukuken belirlenmiş, insan haklarının bir bütün olduğunun altı çizilerek sağlık hakkının da diğer haklarla birlikte yorumlanmasına ışı tutulmuştur ${ }^{9}$. Zira öğretide Evrensel İnsan Hakları Bildirgesi’ni kamu sağlığı açısından da etkili gören görüşler bulunmaktadır. Bu görüşe göre amacı insanların sağlıklı olacağı şartları sağlamak olduğu için Bildirge, kamu sağlığının etkilerini de ortaya koymaktadır. Bu amaç, aynı zamanda kamu sağlı̆̆ının da amacıdır ${ }^{10}$.

\section{Avrupa Sosyal Şartı: Avrupa Sosyal Haklar Sözleşmesi}

Avrupa Konseyi'ne üye devletler, 1950'de Roma'da İnsan Hakları ve Temel Özgürlüklerin Korunması Avrupa Sözleşmesi'ni imzalamalarının ardından, Paris'te 1952'de ek protokol ${ }^{11}$, 1961'de Torino'da bir ek protokol daha imzalamışlardır. 1996 'da ise söz konusu Sözleşme’yi revize etmişlerdir ${ }^{12}$.

7 Döner, Ayhan (2003) İnsan Haklarının Korunması ve Avrupa Sistemi, 1. Baskı, Ankara, Seçkin, s. $35 \mathrm{vd}$..

8 Gemalmaz, Mehmet Semih (2011) Ulusalüstü İnsan Hakları Hukuku Belgeleri, Cilt II, 1. Baskı, İstanbul, Legal, s. 3-20; Ertan, İzzet Mert (2012) Uluslararası Boyutlarıyla Sağlık Hakkı, 1. Baskı, İstanbul, Legal, s. 18-19.

9 Temiz (2013), s.72-73.

10 Annas, George J. (2005) Human Rights and Helath: The Universal Declaration of Human Rights at 50, Perspectives on Health and Human Rights, New York-London, Routledge, s. 68.

11 Demir (2006), s. 1410.

12 TBMM, Avrupa Şartı Sosyal (Değiştirilmiş $<$ https://www.tbmm.gov.tr/komisyon/kefe/docs/ sosyalsart.pdf>, s.e.t.17.02.2020. 
Sözleşme "ulaşılabilecek en yüksek sağlık düzeyi”ni belirlemesi nedeniyle DSÖ Anayasası tarafından benimsenen sistematiği izleyen ilk belge özelliği taşımaktadır ${ }^{13}$. Sözleşme ile üye devletler, halklarına belgedeki kişi hakları ile siyasal hak ve özgürlükleri sağlamayı görev edinmiştir. Sözleşme’de hiçbir ırk, renk, cinsiyet, din, siyasal düşünce farkı gözetilmeksizin sosyal haklardan herkesin yararlanabilmesi için hükümler getirilmiştir. Kentlerde ve kırsalda yaşayan kişilerin yaşam kalitesini ve sosyal refahını artırmak amacıyla düzenlemeler yapılmıştır. Güvenli ve sağlıklı koşullarda çalışma, sağlığın korunması, sosyal güvenlik, sağlık ve sosyal yardım, sosyal ve refah hizmetlerinden yararlanma, bedensel ya da zihinsel özürlülerin mesleki eğitimi, mesleğe ve topluma yeniden uyum sağlama gibi haklar Sözleşme’de yer almaktadır ${ }^{14}$.

Türkiye Cumhuriyeti de 1996'da bazı maddelere çekince koyarak Sözleşme'yi imzalamıştır ${ }^{15}$. Çekince koyulan maddelerin Türkiye'yi bağlayıcılığı bulunmamaktadır' ${ }^{16}$.

\section{Uluslararası Ekonomik, Sosyal ve Kültürel Haklar Sözleşmesi}

Evrensel İnsan Hakları Bildirgesi ${ }^{17}$, medeni ve siyasal haklar ile sosyal ve kültürel hakları bir arada düzenlemektedir. Bu Bildirge, 1966'da iki ayrı sözleşmeye dönüşmüştür ${ }^{18}$. İlk kuşak hakları içeren 1976 'da yürürlüğe giren, Uluslararası Ekonomik, Sosyal ve Kültürel Haklar Sözleşmesi'dir. Sözleşme’nin 12. maddesi, sözleşmeye taraf olan devletlerin herkese, ulaşılabilecek en yüksek seviyede bedensel ve ruhsal sağlık standartlarından yararlanma hakkını tanıyacağını ve devletin bu konuya ilişkin alması gereken önlemlerini içermektedir ${ }^{19}$.

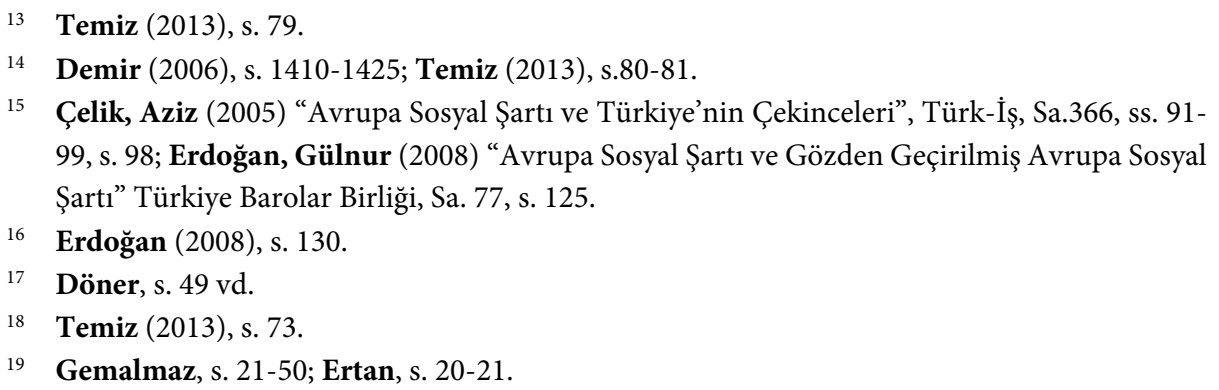


Uluslararası Ekonomik, Sosyal ve Kültürel Haklar Sözleşmesi ile sağlık hakkı, ulaşılabilir en yüksek düzeyde fiziksel/bedensel ve ruhsal sağlık standartlarından yararlanma hakkı olarak tanımlanmış ve Evrensel İnsan Hakları Bildirgesi'ndeki yaşama standardının bileşeni konumundan uzaklaşarak ayrı bir hak şeklinde düzenlenmiştir ${ }^{20}$.

Birleşmiş Milletler Ekonomik ve Sosyal Konseyi'nin 1985 tarihli ve 1985/7 sayılı kararıyla kurulmuş olan Ekonomik, Sosyal ve Kültürel Haklar Komitesi, 2006 yllı itibariyle 18 adet genel yorumu sözleşmeye taraf devletlerin bilgisine sunmuştur ${ }^{21}$. He ne kadar yorum adı altında olsa da bu metinler de uygulanma gereklilikleri yahut uygulamayı yönlendirme kabiliyetleri vardır. Özellikle 2000 yllında 22. oturumda sunulan 14 sayılı genel yorumda ${ }^{22}$ DSÖ’nün tanımlarını temel alan şekilde sağlık hakkının tanımı ${ }^{23}$, boyutları ${ }^{24}$, devletin sağlık hakkına dair üçlü ödevleri ${ }^{25}$ gibi sağlık hizmeti ve sağlık hakkına ilişkin esaslar yer almaktadır. Genel yorumda bahsi geçen başlıkların tüketici değil, yol gösterici olduğu ${ }^{26}$ da belirtilmektedir.

\section{Uluslararası Medeni ve Siyasal Haklar Sözleşmesi}

Evrensel İnsan Hakları Bildirgesi'nde düzenlenen medeni ve siyasal hakların yer aldığı 1966'da imzalanıp, 1976'da yürürlüğe giren ikinci sözleşme ise Uluslararası Medeni ve Siyasal Haklar Sözleşmesi'dir ${ }^{27}$. Bu Sözleşme, doğrudan sağlık hakkını düzenlememekle birlikte sağlık hakkı ile yakın ilişkide olup, ayrı düşünülemeyen yaşama hakkını düzenlemektedir. 6. Maddede, yaşama hakkına dair Sözleşme’nin denetim organı olan İnsan Hakları Komitesi, taraf devletlerce alınması gereken üç önlemden bahsetmektedir. Bunlar; bebek ölümlerinin azaltılması, yetersiz beslenmenin ve salgın hastalıkların ortadan

\footnotetext{
20 Ertan, s. 21.

21 Uyar, Lema (2006) Birleşmiş Milletler'de İnsan Hakları Yorumları İnsan Hakları Komitesi ve Ekonomik, Sosyal ve Kültürel Haklar Komitesi, 1981-2006, 1. Baskı, İstanbul, İstanbul Bilgi Üniversitesi Yayınları, s. xvi.

22 Uyar, s. 236-264.

23 Uyar, s. 236; Temiz(2014),s. 167.

$24 \quad$ Uyar, s. 239; Temiz(2014),s. 169.

25 Uyar, s. 250-251; $\operatorname{Temiz}(2014)$,s.177.

26 Uyar, s. 242; Temiz (2014), s. 180.

27 Döner, s. 41 vd.; Temiz (2013), s. 73.
} 
kaldırılmasıdır. Devletlerin yaşama hakkı ile ilgili alması gereken önlemler sağlıklı yaşamdan çok yaşamın varlığını sürdürmeye yönelik olsa da sağlık hakkı ile doğrudan ilgili olduğu ${ }^{28}$, sağlık hizmeti kapsamında yer aldığı ortadadir.

\section{Avrupa İnsan Hakları Sözleşmesi}

1950'de Roma'da imzalanan, Türkiye tarafından 1952'deimzalanıp 1954’te Resmi Gazete (R.G.)'de yayımlanan Avrupa İnsan Hakları Sözleşmesi (AİHS) de Uluslararası Medeni ve Siyasal Haklar Sözleşmesi’nde olduğu gibi doğrudan sağlık hakkı düzenlemesi içermemekte, 2. maddesinde yaşama hakkına dair açıklamalar içermektedir. Bu madde, herkesin yaşama hakkının yasa tarafından korunmasını öngörmektedir ${ }^{29}$.

Herkesin yaşama hakkının yasa tarafından korunabilmesi için devletin yerine getirmesi gereken yükümlülükler vardır. Bunların başında, kişilerin yaşamlarının devlet ajanları tarafından keyfi surette sona erdirilememesi gelmektedir. Kolluk kuvvetleri gibi kamu kurumunda çalışan personel de devlet ajanı niteliğindedir. Avrupa İnsan Hakları Mahkemesi (AİHM) Tarariyeva v. Russia $^{30}$ kararında sağlık personelinin devlet ajanı olduğu ve eylem ile ihmallerinden devletin sorumlu olduğu belirtilmiştir. AİHM'in Association X v. United Kingdom ${ }^{31}$, Osman v. The United Kingdom ${ }^{32}$, Powell v. The United

28 Gemalmaz, s. 95-146; Ertan, s. 135-136.

29 Ertan, s. 131; Demir, Simge (2018) Kamu Görevlisi Hekimlerin Trbbi Müdahaleden Kaynaklanan Sorumluluğu, 1. Baskı, Ankara, Seçkin, s. 237.

30 Case of Tarariyeva v. Russia, Application No. 4353/03, Judgment 14/12/2006, Para. No. 74, $<$ https://www.legal-tools.org/doc/a6ab2f/pdf/>, s.e.t.17.02.2020.

31 Kararda taraf devletlerin yalnızca kasten kişinin yaşamını son vermemesinin yeterli olmadığı, hayat kurtarmak için de uygun önlemler almasının gerektiği düzenlenmiştir. Case of Association X . V/The United Kingdom, Application No. 7154/75, Judgment 12/07/1978, Para. $\quad$ No. $8, \quad$ s. $\quad 32, \quad<$ http://hudoc.echr.coe.int/eng\#\{"appno": ["7154/75"]\}>, s.e.t.17.02.2020.

32 Kararda üye devletlerin kişiler arası yaşama haklarının ihlali niteliğindeki davranışların önüne geçilmesi için yükümlülükleri olduğu belirtilmiştir. Case of Osman v. The United Kingdom, Application No. 87/1997/871/1083, Judgment 28/10/1998, Para. No. 107, s. 30, $<$ https://hudoc.echr.coe.int/eng\#\{\%22fulltext $\% 22$ :

[\%22osman\%22],\%22itemid\%22:[\%22001-58257\%22]\}>, s.e.t.17.02.2020. 
Kingdom $^{33}$, Calvelli and Ciglio v. Italy ${ }^{34}$, Cyprus v. Turkey ${ }^{35}$ ve Oyal v. Turkey ${ }^{36}$ kararları da sağlık hakkı ve sağlık hizmetleri açısından devletlerin yükümlülükleri ile ilgili açıklamaları nedeniyle önem taşımaktadır.

\section{Dünya Tabipler Birliği Bildirgeleri}

Dünya Tabipler Birliği (DTB) tarafından ilk olarak 1947'de yayınlanan, içerdiği ilkeler nedeniyle Hipokrat Yemini'nin modern versiyonu olarak adlandırılan Cenevre Bildirgesi, DTB’nin günümüzdeki politikalarını içeren çok az değişime uğramış daimi bildirgedir ${ }^{37}$.

33 Kararda yetkililerin sağlık bakımına dair eylem ve ihmallerinin taraf devletlerin yaşama hakkının korunması yükümlülüklerinin ihlaline ve devletlerin sorumluluğuna neden olabileceği belirtilmiştir. Sağlık alanındaki bilgilendirme hatası, ihmal, hatalı müdahale vb. hallerin de devletin pozitif yükümlülüğünün ihlaline neden olduğu açıklanmıştır. Case of Powell v. The United Kingdom, Application No. 45305/99, Judgment 04/05/2000, s. 17-18 $<$ http://hudoc.echr.coe.int/eng\#\{"fulltext":["powell"],"itemid":["001-5215"]\}>, s.e.t.17.02.2020.

34 Kararda kamu/halk sağlığına, kamu/özel hastanelerin hastalarının yaşama haklarını koruyucu önlemleri alınması gerektiğine ve özel/kamu hastanesindeki tıbbi müdahaleden ölenlerin ölüm nedeninin belirlenebilmesi ve sorumlu olanlara başvurulabilmesi için bağımsız bir yargı sisteminin gerektiğine dikkat çekilmiştir. Case Of Calvelli v. $\begin{array}{llll}\text { Italy,Application } & \text { No. } & 32967 / 96, & \text { Judgment }\end{array}$ $<$ https://hudoc.echr.coe.int/eng\#\{"fulltext":["ciglio"], "documentcollectionid2":["GRANDCHAMBER","CHAMBER"],"itemid":["001-60329"]\}>, s.e.t.17.02.2020.

35 Kararda yaşama hakkı ile sağlık hizmetinin icrası arasında ilişki kurularak, sağlık hizmetinin icra edilmemesi halinde devletin yaşama hakkının ihlalinden sorumlu olacağı belirtilmiştir. Case of Cyprus v. Turkey, Application No. 25781/94, Judgment 10/05/2001, Para. No. 219, s. 3 , $<$ http://hudoc.echr.coe.int/eng\#\{"display": ["0"],"languageisocode":["TUR"],"appno":["25781/94"],"documentcollectionid2":["GRANDC HAMBER"]\}>, s.e.t.17.02.2020.

36 Kararda kamu kurum ve kuruluşlarında gerçekleştirilen kan nakli nedeniyle bozulan sağlık durumlarından devletin pozitif yükümlülüğün ihlali nedeniyle sorumlu olacağ açıklanmıştır. Case of Oyal v. Turkey, Application No. 4864/05, Judgment 23/06/2010, Para. No. $\quad 6,7,8,9,10,72, \quad$ s. $\quad 2,3,21, \quad<$ http://hudoc.echr.coe.int/eng\# \{"fulltext":["4864/05"],"display":["0"],"itemid":["001-162088"]\}>, s.e.t.17.02.2020.

37 https://www.wma.net/what-we-do/medical-ethics/declaration-of-geneva/, s.e.t.17.02.2020. 
1964'te yayınlanan DTB'nin en bilinen politikalarını içeren Helsinki Bildirgesi $^{38}$, yedi kere değişime uğrayarak, son halini 2013'te almış olup, bu haliyle uygulamadadır ${ }^{39}$.

Tokyo Bildirgesi ise DTB’nin kuruluşundaki nedenlerin İkinci Dünya Savaşı'nda doktorların tıbbi araç-gereçleri, ilaçları insan üzerinde kullanmaları, deney yapmaları ile ilgili davaların çokluğu, bu durumların hala dünyanın çeşitli yerlerinde devam etmesi, bunların önüne geçilmesi olduğunu belirtmektedir. Bildirge'de tıbbi müdahale ile kişilere işkence eden doktorların davranışlarının etik olmamasının yanı sıra, kişilerin doktorlara olan güvenlerini de sarsacağı, zorlamaya maruz kalsalar dahi doktorların işkenceden uzak durmaları gerektiği konularına dikkat çekilmiştir ${ }^{40}$.

Taipei Bildirgesi ise insanlar üzerinde tıbbi araştırmalar konusunda bir rehber niteliğinde olan Helsinki Bildirgesi ile birlikte ele alınmaktadır. Bildirge'de kişiler üzerinde tıbbi araştırma yapılmadan önce aydınlatılmış onam alınması üzerinde durulmuştur. Sömürü ve suistimale uğrama riskine karşılık, sağlık problemlerinin çözülmesi amacıyla veriler kişilerin rızası alınarak yüksek koruma altına alınmalı, araştırmalar yapılarak hastalıkların tedavisi bulunmalıdır. Taipei Bildirgesi, kişilerin özel hayatına giren bu verilerin veritabanlarında ve biyobankalarda yüksek standartlarda en iyi koruma yöntemleri ile ticari, idari ve politik sömürülere karşı korunması politikalarını kapsamaktadır. Bu Bildirge sayesinde, aydınlatılmış onam ile hastalardan alınan veriler ve numunelerin korunmasına ilişkin sorumluluk üstlenilmektedir ${ }^{41}$.

\section{Alma Ata Bildirgesi}

Alma Ata Bildirgesi' ${ }^{42}$, DSÖ tarafından 1978'de Kazakistan'ın başkenti Alma Ata'da Temel Sağlık Hizmetleri Uluslararası Konferansı neticesinde yayınlanmıştır. Bildirge'nin önemi, temel sağlık hizmetlerinin öneminin

\footnotetext{
38 Kizılarslan, Hakan (2007) Ceza Muhakemesi, Adli Tip, Adli Bilimlerde Vücudun Muayenesi ve Örnek Alma Doktrin ve Uygulama, 1. Baskı, Ankara, Çetin Veb-Ofset A.Ş., s. 70. https://www.wma.net/what-we-do/medical-ethics/declaration-of-helsinki/, s.e.t.17.02.2020. https://www.wma.net/what-we-do/medical-ethics/declaration-of-tokyo/, s.e.t.17.02.2020. https://www.wma.net/what-we-do/medical-ethics/declaration-of-taipei/, s.e.t. 17.02.2020.

42 Kizılarslan, s. 70.
} 
vurgulanması ile sağlık hakkının temel insan hakkı olduğunun kabul edilmesidir. Bildirge ile sağlık kavramı DSÖ’ye üye Avrupa ülkeleri başta olmak üzere dünya geneli tüm ülkelerde temel değer konumuna gelmiştir ${ }^{43}$.

DSÖ, 1973'te sağlığa verilen değerin azlığına dikkat çekmek adına "herkes için sağlık" politikasını benimsemiştir. Bu politika ile sağlık hizmetlerinin tüm toplum tabanına yayılması, ücretsiz, teknolojik olanaklardan maksimum seviyede faydalanarak herkesin gereksinimi ölçüsünde yararlanması hedeflenerek temel sağlı hizmetleri vurgulanmış ${ }^{44}, 2000$ yılı kalkınmanın ön koşulu olarak temel sağlık hizmetlerinin iyileştirilmesi hedefi gösterilmiş ve "2000 Yılında Herkes İçin Sağlık Bildirgesi” yayınlanarak çalışmalara başlanmıştır ${ }^{45}$. Tüm ülkelere iç ve dış kaynaklarını kullanmaları, sağlık hizmetini iyileştirmeleri yönünde çağrıda bulunulmuştur. Bu çalışmalar sonucunda tüm dünyada sağlık hizmetine ilişkin kayda değer gelişmeler yaşanmıştır ${ }^{46}$.

\section{Lizbon Bildirgesi}

1981'de yayınlanan Lizbon Bildirgesi ${ }^{47}$ nde tıp mesleğinin hastalara sağlamaya çalıştığı temel hakların bir kısmı bu bildirgede yer almaktadır ${ }^{48}$. Hasta hakları, dış baskıdan uzak bir şekilde çalışabilen hekim tarafından tedavi edilme, hekimi seçebilme, tıbbi ve kişisel bilgilerin gizliliği, yeterli bilgilendirme

43 Temiz (2013), s. 78; Madenoğlu Kıvanç, Meral (2015) "Evrensel Sağlik Bildirgeleri ve Türkiye'de Sağlık Reformları” Sağlık ve Hemşirelik Yönetim, C. 2, Sa. 3, ss. 162-166, s. 163; Çınar, Ülkü (2003) “Sağlık Hukuku” (Doktora), İstanbul Üniversitesi Adli Tıp Enstitüsü, s. 5; Aktan, Coşkun Can/Işık, A. Kadir, Sağlığın Korunması ve Geliştirilmesine Yönelik Evrensel Sağlık Bildirgelerine Toplu Bir Bakış, <http://www.canaktan.org/ekonomi/saglikdegisim-caginda/pdf-aktan/sagligin-korunmasi.pdf>, s.e.t.02.10.2018, ss. 1-34, s. 1-3; Demir (2006), s. 1376-1379; Kızılarslan, s. 70.

44 Aksakoğlu, Gazanfer (2003) "Dünya Sağlık Örgütü ve Sağlık Politikalarında Değişim” Sol, Sa. 199, C. 41-5, ss. 1-7, s. 2; Temiz (2013), s. 78.

45 Yıldız, Hicran/Turan, Mustafa (2010) “Küreselleşme ve Sağlık” Uludağ Üniversitesi Tıp Fakültesi, C. 36, Sa. 1, ss. 39-41, s. 40.

46 Madenoğlu Kivanç, s. 163

47 Kizılarslan, s. 70

48 Demir (2006), s. 1359. 
neticesinde ruhsal yahut manevi yönden tedavi edilmeyi kabul etme veya reddetme, onurlu bir biçimde ölme şeklinde özetlenebilmektedir ${ }^{49}$.

\section{Ottawa Şartı}

Kanada'nın Ottawa kentinde 1986'da düzenlenen I. Uluslararası Sağlı̆̆ 1 Geliştirme Konferansı neticesinde "Sağlığı Geliştirme Ottowa Şartı" yayınlanmıştır. Bu konferansta, 2000 yılı ve sonrasında ulaşılması hedeflenen "Herkes İçin Sağlık" politikası ile herkesin sağlığa kavuşabilmesinin şartları üzerinde durulmuştur ${ }^{50}$. Sağlık hizmetlerine dair sorumluluğa ilişkin kararlar alınarak, sağlık sektörü ile birlikte diğer sektörlerin de bu alandaki sorunlardan sorumlu olduğu benimsenmiştir.

Sağlığın geliştirilme amacı konusu üzerinde durularak, ekonomik, politik, çevresel, biyolojik ve davranışsal etkenlerin sağlığa yararlı bir hale getirilmesinin amaçlardan biri olduğu belirtilmiştir ${ }^{51}$. Sağlığın geliştirilmesi için mevcut şartlara bağlı olması, DSÖ'nün sağlık tanımının üç boyutunu bütünleştirmesi, hükümetlerin sağlık alanındaki sorumluluklarını desteklemesi, sağlığı toplum adına savunması ve sağlığa katılımın esas unsur olması şeklinde beş prensip öngörülmüştür ${ }^{52}$. Bu Belge'nin sağlık hukuku açısından önemi, sorumluluk ve amaca ilişkin önemli kararlar alınmış olmasidir.

Sayek, Füsun (1998) Sağlıkla İlgili Uluslararası Belgeler, 1. Baskı, Ankara, Türk Tabipleri Birliği, s. 32; Madenoğlu Kıvanç, s. 163; Aktan/Işık, s. 3-4

WHO (1986) Ottawa Charter for Health Promotion First International Conference on Health Promotion Otawa, Ottawa, $<$ http://www.who.int/healthpromotion/conferences/previous/ottawa/en/>, s.e.t.17.02.2020, s. 1; Yardım, Nazan/Gögen, Sibel/Mollahaliloğlu, Salih (2009) "Sağlığın Geliştirilmesi; Dünyada ve Türkiye'de Mevcut Durum” İstanbul Tıp Fakültesi, İstanbul, C. 72, Sa. 1, ss. 2935, s. 30.

51 Aktan/Işsk, s. 4; Madenoğlu Kıvanç, s. 163.

52 WHO Secretariat Background Document fort he 6th Global Conference on Health Promotion in Bangkok, "Global Health Promotion Scaling up for 2015- A brief review of major impacts and developments over the past 20 years and challenges for 2015", Thailand, $<$ http://www.who.int/healthpromotion/conferences/6gchp/h pr_conference_background.pdf>, s.e.t.17.02.2020, s. 4-5; Yardım/Gögen/Mollahaliloğlu, s. 30; Aktan/Işsk, s. 4. 


\section{Adelaide Tavsiyeleri}

Avustralya'nın Adelaide kentinde, 1988'de toplanan II. Uluslararası Sağlığı Geliştirme Konferansı'nda "Sağlıklı Halk Politikası" benimsenerek, bu politikanın esasları belirlenmiştir. Bu politika ile sağlık alanındaki eşitsizliklerin giderilerek tüm bireylerin sağlıklı bir yaşam sürmesi amaçlanmaktadır. Sağlıklı Halk Politikası ile sağlığa zararlı olan tütün ve alkolün önüne geçilmesi, gıda ve beslenme ile kadın sağlığına önem verilmesi, sağlığı destekleyici ortamların oluşturulması hedeflenmiștir. Bu politikanın uygulanması esnasında meydana gelebilecek sorunlara ilişkin ülkelerin birlik olması konusu üzerinde de durulmuştur ${ }^{53}$.

12. Herkes için Sağlık Avrupa Bölgesel Hedeflerinin Desteklenmesinde Hemşirelik Hakkında Bildirge

Viyana'da 1988'de Avrupa Hemşirelik Konferansı'nda “Herkes İçin Sağlık" politikasıyla belirlenen hedeflere ulaşmak maksadıyla hemşirelikte değişiklikler yapılması ve bu konuda hemşirelere yardım edilmesinde hükümetlerin ve sağlık alanındaki ulusal karar vericilerin harekete geçirilmesine dair hükümler içeren bir bildirge yayınlanmıştır ${ }^{54}$.

\section{Kopenhag Bildirgesi}

Kopenhag'ta 1994'te DSÖ temsilcilerinin bir araya gelerek sağlık politikalarıyla ilgili yayımladıkları Kopenhag Bildirgesi'nde, Avrupa'da sağlığa ilişkin yapılan eleştiriler ile bu eleştirilerin giderilmesi için yapılması gereken değişiklikler ve gelecekte daha iyi bir durumun hedeflenmesi yer almıştır. $\mathrm{Bu}$ Bildirge'de uluslararası kuruluşlar ile Avrupa Birliği arasındaki işbirliğinin artmasından duyulan memnuniyet belirtilmekle birlikte, gelişime ilişkin adımlar da öneri konusu olmuştur ${ }^{55}$.

\section{Amsterdam Bildirgesi}

Amsterdam'da 1994'te “Avrupa Hasta Haklarının Geliştirilmesi Bildirgesi” adıyla yayınlanan Bildirge'de Lizbon Bildirgesi'ndeki hasta haklarından eksik olanlarına yer verilmiştir. Hekimin hem kendi vicdanına

53 Madenoğlu Kıvanç, s. 163; Aktan/Işık, s. 5.

54 Demir (2006), s. 1390.

55 Madenoğlu Kıvanç, s. 163; Aktan/Işık, s. 7. 
göre hem de hastanın yararına olacak şekilde davranması gerektiği Amsterdam Bildirgesi'nde ${ }^{56}$ dile getirilmiştir. Diğerlerinde olduğu gibi bu Bildirge'de de hastanın bilgilendirilmesi, onayı alınması, özel hayatının gizliliği, bakım ve tedavisi, sağlık hizmetinde insan hakları ile değerleri şeklinde kimi hasta hakları düzenlenmiştir ${ }^{57}$.

\section{Bali Bildirgesi}

Bali'de 1995'te "Dünya Tabipleri Birliği Hasta Hakları Bildirgesi” olarak yayınlanan Bali Bildirgesi ${ }^{58}$, Lizbon ve Amsterdam Bildirgeleri'ndeki konulara benzer konuları ele almıştır. Hastanın kendi kaderini belirleme, kaliteli bakım, seçim, gizlilik, bilgilendirme, sağlık eğitimi alma, dini destek ile onur hakları Bildirge'de bahsedilen hakların başında gelmektedir ${ }^{59}$.

Bali Bildirgesi birkaç konunun ilk defa düzenlenmesi ile farklılığını ortaya koymaktadır. Bunlar, intihar girişimi olan bilinci kapalı hastaya karşı hekimlerin yaklaşımının nasıl olması gerektiği, yasal ehliyeti bulunmayan hastanın rasyonel kararlarına saygı gösterilmesinin gerektiği, sağlık eğitimi düzenlemesi ile herkesin kendi sağlık durumundan kendi sorumlu olduğudur ${ }^{60}$. Bu Bildirge ile temelde hasta haklarının gelişimine yönelik yeni sağlık hakkı ve sağlık hizmeti düzenlemeleri yapıldığı sonucuna varılabilmektedir.

\section{Ljubljana Bildirgesi}

Slovenya'nın başkenti Ljubljana'da 1996'da yapılan konferansta, Avrupa'da sağlık hizmetinden faydalanamayan kişiler için yapılması gerekenler görüşülmüştür. İnsan onuru, sağlı reformları, dayanışma, meslek ahlakı ve hakkaniyet Bildirge' de ${ }^{61}$ yer alan çözüm ilkeleridir ${ }^{62}$.Görüldüğü üzere Ljubljana Bildirgesi de sağlık hakkının korunması ve sağlık hizmetinin dayanağının oluşturulması ve geliştirilmesine ilişkin çeşitli ilkeler barındırarak uluslararası mevzuatta önemli bir yer edinmiştir.

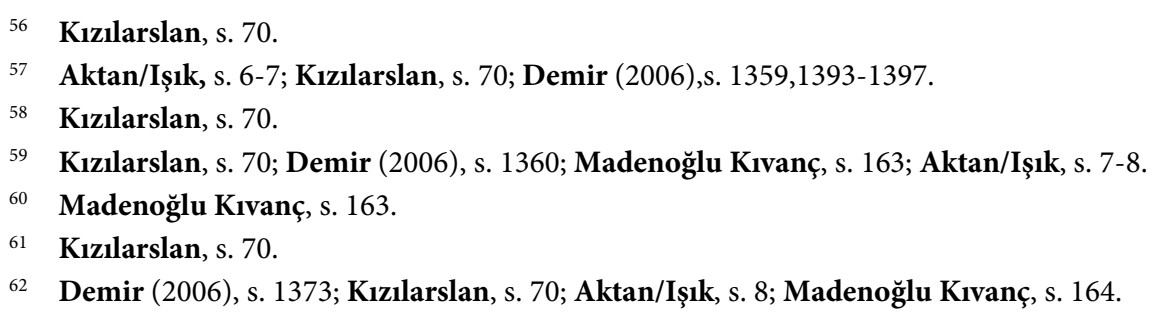




\section{Jakarta Bildirgesi}

Endonezya'nın başkenti Jakarta'da 1997'de düzenlenen IV. Uluslararası Sağlı̆̆ı Geliştirme Konferansı sonucu yayımlanan Bildirge’de, 21. yüzyıl için sosyal sorumluluğun geliştirilmesi, sağlı̆̆ın korunup geliştirilmesi için ortaklıkların kurulup, sürdürülmesi, yatırımların artırılması, bireylerin eğitilip güçlendirilmesi, gerekli altyapı çalışmalarının yapılması gibi yöntemler için çalışmalara başlanması kararı alınmıştır ${ }^{63}$. Jakarta Bildirgesi ile eğitim, yatırım, altyapı gibi önemli konularda yeni düzenlemeler yapılarak sağlık hakkı ile sağlık hizmetinin gelişimine dair önemli adımlar atılmıştır.

\section{Halkların Sağlığı Bildirgesi}

Bangladeş'in Savar kentinde 2000'de 92 ülkenin temsilcisinden oluşan Halkların Sağlı̆̆ı Meclisi toplanarak bildirge yayınlamıştır. Bildirge'de, küresel sağlık krizi ile savaşabilmek adına bireysel, toplumsal, bölgesel ve ulusal olarak harekete geçilmesinin gerektiği belirtilmiştir ${ }^{64}$. Sağlık ve insan haklarının ekonomik ve politik kaygılara nazaran her zaman önde olması gerektiğinin de üzerinde durulmuştur ${ }^{65}$. Halkların Sağlığı Bildirgesi sağlık hakkı ile sağlık hizmetinin ülkeler için oldukça önem arz eden ekonomi ve politikanın üzerinde olduğu belirtilmesi nedeniyle önem taşımaktadır.

\section{Dubrovnik Sözleşmesi}

Hırvatistan'da 2001'de imzalanan bir sözleşmedir. Sağlığın finansman kaynakları ile kalitesi üzerinde durulmasının yanı sıra, sağlık alanında hedef ve stratejiler de belirlenmiştir ${ }^{66}$. Bu sözleşmede, vatandaşlara uygun, yüksek kalitede olduğu kadar elde edilebilir sağlık hizmetini sunmak ve halkın bu hizmete ulaşmasını sağlamak, sosyal birleşmeyi toplum ruh sağlığı hizmetlerini güçlendirmek, kan/kan ürünleri konusunda güvenilirliği kazanmak, ücretsiz acil bakım hizmetlerini kuvvetlendirmek, bulaşıcı hastalıkların kontrolünü sağlayabilmek ve beslenme kaynaklarının elde edilebilirliği ve güvenilirliğini

\footnotetext{
63 Madenoğlu Kıvanç, s. 164; Aktan/Işık, s. 8.

64 Madenoğlu Kıvanç, s. 164.

65 Yıldı/Turan, s. 40-41; Katikireddi, Vittal, (2004) "New Regular Report Will Monitor Global Health Issues”, BMJ, 328, 728, s. 1.

66 Madenoğlu Kıvanç, s. 164.
} 
sağlamak konuları hakkında kararlar alınmıştır ${ }^{67}$. Dubrovnik Sözleşmesi ile sağlık hakkının hem ekonomik boyutu hem de sosyal boyutu ile ele alındığı görülmektedir.

\section{Hasta Haklarına İlişkin Ana Sözleşmesi}

2002 Yılında Roma'da imzaya açılan Hasta Haklarına İlişkin Ana Sözleşmesi ile her ne kadar Avrupa Birliği’ne üye ülkelerin ulusal sağllk sistemleri farklı olsa da hasta, kullanıcı, tüketici, aile bireyleri, risk taşıyan insanlar ve azınlıkların haklarına dair aynı koşulların olduğu savunulmaktadır. Sağlık konusunda dünyanın her yerinde tedavi hakkının varlığına ilişkin Avrupa Sosyal Modeli'ne dair resmi tebliğlerin bulunmasına karşın var olan birçok kısıtlama yahut ihlal, ülkelerin var olduğunu savundukları hakkın sorgulanması ihtiyacını doğurmaktadır ${ }^{68}$.

Her ülkenin ulusal sağlık sisteminde ortak hakların var olduğu ileri sürülse de bu duruma açıklık getirmek adına bu Sözleşme kaleme alınmıştır. Temel haklar, hastalara ait on dört hak (koruyucu tedbirlerin alınması, yararlanma, bilgi, rıza, özgür seçim, özel ve gizlilik, hastaların vaktine sayg,, kalite standartları, güvenlik, yenilik, gereksiz ağrı yahut acı ve sıkıntıdan sakınma, kişisel tedavi, şikâyet, tazminat hakları), aktif vatandaşlık hakları ve Sözleşme'nin uygulama ilkeleri gibi bölümler bulunmaktadır ${ }^{69}$. Bu Sözleşme'nin önemi de hasta hakları üzerinde durularak, bu haklara ve sağlık sistemine ilişkin açıklamalar getirilmesidir.

\section{Tütün Kontrolü Çerçeve Sözleşmesi}

Tütün Kontrolü Çerçeve Sözleşmesi, tütün kullanımına ilişkin kontrol hakkında yapılmış ilk uluslararası sözleşme niteliğini taşımaktadır. 2003 tarihinde 56. Dünya Sağlık Asamblesinde DSÖ'nün denetiminde tüm üye devletler tarafından tartışılıp, imzalanan halk sağlığına ilişkin ilk küresel sözleşme olması nedeniyle önem arz etmektedir. Tütün fiyatlarına, reklam, vergilendirme, sponsorluk, tütünsüz ortam vb.ye uluslararası standartlar getiren bu Sözleşme, 27.02.2004 itibariyle yürürlüğe giren uluslar arası kanun

\footnotetext{
67 Aktan/Ișik, s. 9.

68 Demir (2006), s. 1380.

69 Demir (2006), s. 1381-1389.
} 
niteliğini de kazanmıştır ${ }^{70}$. Böylece bu Sözleşme ile DSÖ, tütün vergilerine, fiyatlarına, reklam, sponsorluk ve promosyonlara, sürveyans ve araştırma metodlarına, kanunsuz satışlara, pasif içiciliğe ve tütünsüz ortamlara ilişkin uluslararası standartlar getirmiştir ${ }^{71}$. Sağlık alanına ilişkin bu kadar önemli olan konularda uluslararası standartlar getirmesi nedeniyle bu Sözleşme oldukça önem arz etmektedir.

\section{Bangkok Konferansi}

Tayland'ın Bangkok şehrinde 2005'te düzenlenen VI. Küresel Sağlığın Geliştirilmesi Konferansı'nda sağlığı geliştirmek için önemli adımlar belirlenmiştir. Bu adımlar, sağlıklı halk politikası oluşturma, destekleyici çevreler düzenleme, topluluk faaliyetlerinin arttırılması, sağlık hizmetinin yönlendirilmesi, bireysel kabiliyetlerin geliştirilmesi vb.dir. Sağlığın geliştirilmesi için devletin temel yükümlülügü haline gelmesi, küresel gelişim gündeminin merkezinde yer alması, ortak uygulamaların olması ve sivil toplum ve toplulukların odak noktası haline gelmesi gerektiği şeklinde dört nokta tespit edilmiştir $^{72}$. Bu Konferans ile devletin yükümlülüklerinin bir kez daha açık bir şekilde altı çizilmesi oldukça önemlidir.

\section{Tallinn Şartı}

Estonya'da 2008'de gerçekleştirilen konferans sonucunda hazırlanan Tallinn Şartı’nın sağlık sistemini güçlendirmeye yönelik stratejik çerçeve ve kılavuz olması hedeflenmiştir. DSÖ'nün son zamanlardaki raporlarının ortak noktalarının olduğu ve bu noktaların sağlı hizmetinin özelleştirilmesinde birleştiği ve bu özelleştirmelere yönelik müdahalelerin varlığına dikkat çekilmiş ve söz konusu raporlar bu konferansta ayrıntıları ile incelenmiştii ${ }^{73}$. Bu

70 Başbakanlık, Ulusal Tütün Kontrol Programı Genelgesi, (2006) No. 2006/29, 26312 Sayılı R.G., Y.T.07.10.2006; Yardım/Gögen/Mollahaliloğlu, s. 32.

71 Yardım/Gögen/Mollahaliloğlu, s. 32.

72 The Bangkok Charter for Health Promotion in a Globalized World, Health Promot, Int. 2006 21 ,

$<$ http://www.who.int/healthpromotion/conferences/6gchp/hpr_050829_\%20BCHP.pdf?ua =1>, s.e.t.17.02.2020, s. 4; Yardım/Gögen/Mollahaliloğlu, s. 30-31; Madenoğlu Kıvanç, s. 164 .

73 Madenoğlu Kıvanç, s. 164. 
bağlamda Tallinn Şartı ile sağlık hizmetindeki özelleştirmeler mercek altına alınmıştır.

\section{Malta Belgesi}

2012'de, DSÖ’nün Avrupa Bölgesi Komitesi'nin 62. toplantısı Malta'da yapılmış olup, toplantı sonucunda Malta Belgesi ${ }^{74}$ yayınlanmıştır. Belge'de, üye devletler ile DSÖ Avrupa Bölge Ofisi için stratejik yönelimler ile öncelikli olarak politik eylem alanları hakkında açıklamalar yapılmıştır. Devlet Sağlık Örgütü'ne üye devletlerden 53'ü yeni politika olan “Sağlık 2020” hakkında anlaşmışlardır. Ortak amaç ise 1988'de yayımlanan Adelaide Tavsiyeleri'nden beri hala giderilememiş olan sağlı alanındaki eşitsizliklerin giderilmesi, insanların sağlık ve esenliğini arttırmak, halk sağlığını güçlendirerek eşitlikçi, evrensel, yüksek kaliteli, sürdürülebilir ve insan odaklı sağlık sistemlerinin oluşturulmasını başarabilmektir ${ }^{75}$.

Bu belgelerin dışında, kadına verilen değerin arttırılması konusunu ele alan 1994'te Viyana'da yayınlanan Orta ve Doğu Avrupa Ülkelerinde Kadın Sağlığı Konferansı: Kadına Yatırım Yapılması Hakkında Viyana Bildirisi, alkol politikalarının düzenlenmesine ilişkin 1995’te Paris'te yayınlanan Sağlıklı Toplum ve Alkol Üzerine Avrupa Konferansı: Alkole İlişkin Avrupa Şartı, 1996 'da yayınlanan biyolojik ve tıbbi uygulamalardaki insan hakları ve temel hakları düzenleyen Avrupa Konseyi İnsan Hakları ve Biyotıp Sözleşmesi ${ }^{76}$, 1997'de UNESCO tarafından genetik hakların koruma altına alınmasına dair Birleşmiş Gen Haritası ve İnsan Hakları Evrensel Bildirgesi, gençler ve alkol konusunu inceleyen 2001'de Stokholm'de yayınlanan Gençler ve Alkol Hakkında Bildirge de sağlık hakkı ve sağlık hizmetine ilişkin önemli hükümler içermektedir ${ }^{77}$.

Kizılarslan, s. 70.

Madenoğlu Kıvanç, s. 164; Kızılarslan, s. 70.

Kizilarslan, s. 71.

77 Demir (2006), s. 1392-1409. 


\section{B. Ulusal Mevzuat}

\section{Sağlık Hakkı ve Sağlık Hizmetinin Türkiye Cumhuriyeti Anayasalarındaki Durumu}

Sağlık hakkının ve sağlık hizmetinin ortaya çıkışının temellerini incelemek için bireylerin hak ve özgürlüklerinin yanı sıra, devletin hizmetlerinin de yer aldığı anayasaların incelenmesi gerekir. Türkiye Cumhuriyeti'nin 1921, 1924, 1961 ve 1982 olmak üzere tarihsel süreçte dört anayasası bulunmakta olup, sırasiyla incelersek:

\section{a. 1921 Anayasas1}

Kurtuluş Savaşı dönemlerinde yeni bir devletin kurulması ümidiyle gerçekleştirilen "Teşkilatı Esasiye Kanunu" adıyla TBMM tarafından 20.01.1921'de çıarılan 23 maddelik 1921 Anayasası, yalnızca o dönem için gerekli olan zaruri ve sınırlı hak ve özgürlükleri içermekteydi ${ }^{78}$, dönemin şartları gereği tüm temel hak ve özgürlükler bu anayasada düzenlenme imkânı bulamamıştı. Bu kapsamda görülmeyen sağlık hakkı ve yaşama hakkı 1921 Anayasası'nda düzenlenememişti. Fikrimizce tüm insan haklarının temelinde bulunan yaşama hakkı ve dolayısıyla sağlık hakkı, en zaruri hak olup, en başta düzenlenmesi gereken haktır. 1921 Anayasası, savaş döneminin ardından çıkarılan Anayasa olması özelliği ile de esasında bu hakları koruma altına almalıydı. Bu yönü ile 1921 Anayasası en önemli hakkı düzenlemeyerek eksik bir nitelik taşıyan anayasa olarak değerlendirilebileceğini belirtmemiz gerekmektedir; ancak öğretide 1921 Anayasası'nda yer almayan konular için 1876 Anayasası'nın yürürlükte olduğu ve hükümlerinin uygulandığı kabul edilmektedir ${ }^{79} .1876$ Anayasası'nda “Tebaa-i Devlet-i Osmaniye’nin Hukuku Umumiyesi” başlığı altında 17 madde halinde temel hak ve özgürlükler düzenlenmişti. Her ne kadar söz konusu 17 madde arasında doğrudan yaşama hakkı veya sağlık hakkı başlığı ile bir hak düzenlenmese de 9. maddede kişi hürriyeti düzenlemesinin içerisinde hüküm altına alınmıştı.

78 Tanör, Bülent (2010) Osmanlı-Türk Anayasal Gelişmeleri, 19. Baskı, İstanbul, Yapı Kredi, s. 253.

79 Mumcu, Ahmet/Küzeci, Elif (2015) İnsan Hakları ve Kamu Özgürlükleri, 7. Baskı, Ankara, Turhan, s. 194,195; Tanör, s. 267; Özbudun, Ergun (2016) Türk Anayasa Hukuku, 16. Baskı, Ankara, Yetkin, s. 28. 


\section{b. 1924 Anayasasi}

1924 Anayasası'nda ise temel hak ve özgürlükler düzenlenmiş, 70. ve 71. maddede yaşama hakkı ile ilgili normlar getirilmiştir. 70. Maddede, "Şahsi masuniyet, vicdan, tefekkür, kelam, neşir, seyahat, akit, sayü amel, temellük ve tasarruf, içtima, cemiyet, şirket, hak ve hürriyetleri Türklerin tabii hukukundandır.", 71. maddede, "Can, mal, ırz, mesken her türlü taarruzdan masundur." ifadeleri Türk anayasalarında yaşama hakkının ilk düzenleniş şekli olarak ele alınmaktadır. Sağlık hakkı doğrudan 1924 Anayasası'nda düzenlenmese de yaşama hakkı düzenlenerek sağlık hakkının temellerini oluşturmuştur.

\section{c. 1961 Anayasas1}

Sosyal alanlar, temel anayasal tercihlere göre ilk aşamada anayasaların dışında tutulmuştur; ancak sonraki anayasal tercihlerde sosyal alanların da anayasalara girmesi yolunda çalışmalara başlanmış, sosyal nitelik taşıyan maddeler de anayasalara dâhil olmuştur. Eşitlikçi bir yaklaşımla düzenlenen bu hükümler, kişilerin kişi hakları ve siyasi hakları kullanabilmesi için de gerekli olan barınma, beslenme, eğitim ve sağlık gibi temel ihtiyaçların, hakların sağlanması anlayışını temel alır. İnsan Hakları Evrensel Beyannamesi'nin özellikle 22, 25 ve 26. maddelerinde belirtilen tıbbi bakım, beslenme, barınma, sosyal güvenlik, eğitim gibi hakların tanınması ve bu hakların yerine getirilmesi, temel gereksinimlerin karşılanması anlayışı neticesinde yapılan düzenlemelerdir ${ }^{80}$.

1961 Anayasası II. Dünya Savaşı'ndan sonra T.C.'de yapılmış olan ilk anayasadır. Sosyal devlet anlayışı da II. Dünya Savaşı'nın ardından ortaya çıkmış olup, anayasalara dahil edilmiş ${ }^{81}$,yaşama hakkının yanı sıra, sosyal ve ekonomik haklar kapsamında değerlendirilen sağlık hakkı ve tüm temel hak ve ödevler de bu dönemden sonra anayasalarda bulunmaya başlamıştır ${ }^{82} .1961$ Anayasası'nın "Kişinin Hak ve Ödevleri” bölümünün "Kişi Dokunulmazlığı"

80 Oder, Bertil Emrah, (2008) "Devletin Olumlu Edimine Gerektiren Sosyal Hakların Anayasal Düzeyde Korunması ve Yargısal Tutumlar” Galatasaray Üniversitesi Hukuk Fakültesi, C. 1, ss. 199-231, s. 202-205.

Oder, s. 206.

82

Çınar, s. 24; Temiz (2013), s. 53. 
başlıklı 14. maddesinde "Herkes, yaşama, maddi ve mânevi varlı̆̆ını geliştirme haklarına ve kişi hürriyetine sahiptir. Kişi dokunulmazlı̆ğ ve hürriyeti, kanunun açıkça gösterdiği hallerde, usulüne göre verilmiş hâkim kararı olmadıkça kayıtlanamaz. Kimseye eziyet ve işkence yapılamaz. Insan haysiyetiyle bağdaşmayan ceza konulamaz." ifadesi ile yaşama hakkı düzenlenmiştir. 1961 Anayasası 1924 Anayasası'ndan farklı olarak, yaşama hakkının yanı sıra, sağlık hakkını da koruma altına almıştır. "Sosyal ve İktisadi Haklar ve Ödevler" bölümünde 49. maddede yer alan sağlık hakkı, "Devlet, herkesin beden ve ruh sağlığı içinde yaşıyabilmesini ve tıbbi bakım görmesini sağlamakla ödevlidir. Devlet, yoksul veya dar gelirli ailelerin sağlıkşartlarına uygun konut ihtiyaçlarım karşılayıcı tedbirleri alır.” düzenlemesi ile anayasal güvence kazanmıștır. Bu maddede sağlık hakkı ile birlikte “...herkesin beden ve ruh sağlığı içinde yaşıyabilmesi...” şeklinde ifade ettiği yaşama hakkını koruyucu hüküm de yer almaktadır. Söz konusu madde ile devlete herkesin beden ve ruh sağlı̆̆ içinde yaşaması ödevi yüklenmiştir ${ }^{83}$. Böylelikle devletin sağlık hakkı ve yaşama hakkını birlikte ele aldığını anayasal anlamda da görmüş bulunmaktayız.

\section{ç. 1982 Anayasası}

1961 Anayasası'nda benimsenmiş olan sosyal devlet anlayışı, 1982 Anayasası'nda da varlığını sürdürmektedir ${ }^{84}$. Aynı zamanda 1961 Anayasası'nda düzenlenen temel hak ve özgürlükler, 1982 Anayasası'nda da yerini korumaktadır. "Kişinin Hakları ve Ödevleri” bölümünde, "Kişinin Dokunulmazlığı, Maddi ve Manevi Varlı̆̆ı” başlığı taşıyan 17. maddesinde, "Herkes, yaşama, maddi ve manevi varlığını koruma ve geliştirme hakkına sahiptir. Tıbbi zorunluluklar ve kanunda yazıl haller dışında, kişinin vücut bütünlüğ̈̈ne dokunulamaz; rızası olmadan bilimsel ve tıbbi deneylere tabi tutulamaz. Kimseye işkence ve eziyet yapılamaz; kimse insan haysiyetiyle bağdaşmayan bir cezaya veya muameleye tabi tutulamaz. Meşru müdafaa hali, yakalama ve tutuklama kararlarinin yerine getirilmesi, bir tutuklu veya hükümlünün kaçmasının önlenmesi, bir ayaklanma veya isyanın bastırılması, sikıyönetim veya olağanüstü hallerde yetkili merciin verdiği emirlerin uygulanması sırasında silah kullanılmasına kanunun cevaz verdiğ zorunlu

\footnotetext{
83 Temiz (2013), s. 51.

84 Temiz (2013), s. 54.
} 
durumlarda meydana gelen öldürme fiilleri, birinci fikra hükmü dışındadır." düzenlemesiyle yaşama hakkı anayasal güvence kazanmıştır. Ayrıca bu düzenleme, insan onuru ile beden bütünlügünün yanı sıra, sağlığa müdahaleyi de yasaklaması nedeniyle yaşama hakkı ile sağlık hakkının normatif açıdan da bağlantılı olduğuna delalet etmektedir ${ }^{85}$. "Sosyal ve Ekonomik Haklar ve Ödevler" bölümünde ise "Sağlık Hizmetleri ve Çevrenin Korunması" başlıklı 56. maddede sağlık hizmeti düzenlenmekte olup, sağlık hakkına dair tam anlamıyla bir düzenleme getirilmediği görülmektedir. Maddenin üçüncü fikrasında ise “...Devlet, herkesin hayatını, beden ve ruh sağlı̆̆ sürdürmesini sağlamak; insan ve madde gücünde tasarruf ve verimi artırarak, işbirliğini gerçekleştirmek amacıyla sağlık kuruluşlarını tek elden planlayıp hizmet vermesini düzenler...” şeklinde "beden ve ruh sağlığg”ndan söz edilerek sağlık hakkından kısmen de olsa bahsedilmektedir ${ }^{86}$.

\section{Sağlık Hakkının ve Sağlık Hizmetinin Yasal ve İdari} Düzenlemelerdeki Durumu

Türkiye'de Kurtuluş Savaşı'nın ardından Türkiye Cumhuriyeti’nin kurulmasıyla özellikle 1928'den günümüze sağlıkla ilgili birçok yasal ve idari düzenleme çıarılmış ve sağlık sistemi oluşturulmaya çalışılmıştır. Çalışmamızda sağlık hakkı ve sağlık hizmeti için en çok önem teşkil eden düzenlemeler açıllanma imkânı bulmuştur.

\section{a. Tababet ve Şuabatı Sanatlarının Tarzı İcrasına Dair Kanun}

1928'de 863 sayılı R.G.'de yayımlanan 1219 Sayılı Kanun, Kurtuluş Savaşı'nın ardından sağlık ile ilgili yapılan ilk mevzuattır. Sağlık hizmetinin yerine getirilmesinden sorumlu sağlık personeli, bu personelin hangi özellikleri taşıması gerektiği ayrıntıları ile düzenlenmesinin yanı sıra, Tabip Odaları'nın düzenlendiği ilk yasa olma özelliğini de taşımaktadır ${ }^{87}$.

Temiz (2013), s. 59.

86 Çınar, s. 31; Temiz (2013), s. 60-65.

87 Köroğlu, Ertuğrul (1984) Sağlık Personelini İlgilendiren Hukuk Kuralları Sağlık Mevzuatı, 1. Baskı, Ankara, Hacettepe Yayın Birliği\&Yargıçoğlu, s. 313-323; Çınar, s. 55-56. 
1219 Sayılı Kanun günümüz Türkçesi ile "Tıp Bilimi ve Uzmanlık Dalları ile İlgili Mesleki Kuralların Uygulanmasına Dair Kanun” olarak ifade edilebilir. Sağlık hizmetinin taşıdığı önem ve sağlık kurumlarının tam olarak oluşturulamadığı yerlerde, ekip ile sağlı hizmetinin yerine getirilmesini açıklaması bakımından da bu düzenleme önem arz etmektedir ${ }^{88}$.

1219 Sayılı Kanun'da sağlık personeli tanımlanmış, tabipler, diş tabipleri, ebe, hemşire, hastabakıcı olarak adlandırılan bu kişilerin eğitimleri, diploma almaları gerektiği ve bu belgelerin Sağlık Bakanlığı tarafından onaylanması gerektiği, aksi durumda bu sıfatları alamayacak ve görevi de yapamayacakları, kanunda yer alan kuralların ihlali halinde karşılaşacakları yaptırımlar düzenlemiştir ${ }^{89}$.

\section{b. Umumi Hifzıssıhha Kanunu}

1930'da 1489 sayılı R.G.'de yayımlanan 1593 Sayılı Kanun, yıllar içerisinde değişikliğe uğramış olsa da halen yürürlükte olup, sağlık alanında uygulanan kanunların başında gelmektedir ${ }^{90}$.

Sağlık teşkilatı, sari ve salgın hastalıklarla mücadele, göçmenlerle ilgili sağlık işlemleri, çocuk hıfzıssıhhası, çalışanların sağlığının korunması, şehir ve kasabalar hıfzıssıhhası, şehir ve kasabalarda sağlığın korunması, sağlık istatistikleri, sağlıkla ilgili coğrafik bilgiler ve sağlık propagandası vb. konuları içermekte olan Kanun, sağlık hizmetine ilişkin birçok esası düzenlemiştir ${ }^{91}$.

Umumi Hıfzıssıhha Kanunu'nun sağlık sistemindeki önemi, sağlık hizmetinin kamu hizmeti niteliği taşıdığını, devletin bu hizmeti sunmasının bir yükümlülük olduğunu, bireyin ve toplumun sağlığının korunup geliştirilebilmesi için sağlık hizmetinin ekip çalışması ile yerine getirilmesi gerektiğini belirtmesidir. Bu durumlara "Sağlık Teşkilatı" bölümünün 1 . maddesinde yer alan, "Memleketin sihhi şartlarını ıslah ve milletin sihhatine zarar veren bütün hastalıklar veya sair muzır amillerle mücadele etmek ve müstakbel neslin sihatli olarak yetişmesini temin ve halkı tıbbi ve içtimai

\footnotetext{
Çinar, s. 55.

Çınar, s. 55; Demir (2006), s. 79-93.

Köroğlu, s. 1-43; Temiz (2013), s. 48, 83, 84.

Demir (2006), s. 33-78; Temiz (2013), s. 83-84.
} 
muavenete mazhar eylemek umumi Devlet hizmetlerindendir." hükmü açıklık getirmiştir. Sağlı hizmetine ilişkin uygulama, bu madde gibi diğer hükümlerinde de işlendiği için bu Kanun halen yürürlüktedir ${ }^{92}$.

Bireyin ve toplumun sağlığını koruyup geliştirme ve yeni nesillerin de sağlıklı olmasını sağlamak adına ihtiyaç duyulan sağlık hizmetinin temel kamu hizmeti olduğ $\mathrm{u}^{93}$ günümüzde bilinmektedir; ancak dönemin şartları içerisinde hükümleri incelenirse, Umumi Hıfzıssıhha Kanunu'nunu dönemden bu tanımı sağlamaya çalıştığı sonucuna varılabilmektedir ${ }^{44}$.

\section{c. Hususi Hastaneler Kanunu}

1933 'te 2419 sayılı R.G.'de yayımlanan 2219 sayılı Hususi Hastaneler Kanunu, çok az maddesi değiştirilerek günümüze gelen ender kanunlardan biridir $^{95}$. 1933'te sağlık hizmetinin yalnızca kamu kurum ve kuruluşları tarafından yerine getirilmesi sağlık personelinin yetersizliği açısından mümkün değildi. Bu Kanun ile güçlerin birleştirilip, özel kesim ile kamu kesiminin birlikte çalışması ve yetişmiş sağlık personelinin iki alanda da çalışması söz konusu olabilmiştir ${ }^{96}$.

Hususi Hastaneler Kanunu, özel hastanelerin tarifleri ve açılma şartları, örgütlenmesi, görevleri ve cezai hükümler bölümlerinden oluşmakta ve bu konuları ayrıntıları ile hüküm altına almaktadır ${ }^{97}$.

\section{ç. Türk Tabipleri Birliği Kanunu}

1953’te 8323 sayılı R:G.'de yayımlanan 6023 Sayılı Kanun, Türkiye sınırları içerisinde ister serbest ister özel/kamu kurumlarında görev yapan hekimlerin mesleği icra edebilmeleri için katılmalarının şart olduğu, haklarını koruyan, meslek etiğini düzenleyen kamu kurumu niteliğindeki meslek kuruluşu olan Türk Tabipler Birliği'nin kuruluşunu, hizmetlerini, tabip

\footnotetext{
92 Çınar, s. 59-60.

93 Temiz (2013), s. 144-147, 152-153; Öztekin Ali (2015) “Devletin Asli Ve Sürekli Görevleri (Temel Kamu Hizmetleri) Ve Özellikleri”, Akdeniz İktisadi ve İdari Bilimler Fakültesi, Sa.30, ss.10-19, s.14.

94 Çınar, s. 60.

95 Köroğlu, s. 488-495.

96 Çinar, s. 60-61.

97 Demir (2006), s. 121-127.
} 
odalarının gelirlerini, organlarını vb. içeren bir kanundur ${ }^{98}$. Günümüzdeki Türk Tabipler Birliği’ne uygun hükümler içermesi nedeniyle halen geçerliliğini korumaktadır.

\section{d. Tıbbi Deontoloji Nizamnamesi}

Türk Tabipleri Birliği Kanunu’na dayanılarak, 1960’ta 10436 sayılı R.G. ile yürürlüğe girmiştir. Hekimlerin ve diş hekimlerinin birbiri ile ve hastaları ile aralarındaki ilişkiyi, etik değerleri düzenleyen ve "Hekimlik Mesleği ile İlgili Etik Kurallar Tüzüğü” olarak da adlandırılan bir düzenlemedir. Bu Nizamname, tıp mesleğinde belli standartlar getirerek, herkesin belli olaylar karşısında aynı tepkileri vermesini sağlamaktadır. Bu standartlar ile hekimlerin insan onuruna saygılı ve özverili bir şekilde hareket etmelerine katkı sağlamakta, hekimler arasındaki ilişkiyi artırarak mesleki dayanışma içinde olmalarına da vesile olmaktadır ${ }^{99}$.

Tıbbi Deontoloji Nizamnamesi, yayımlandığı şekli ile günümüze kadar yürürlüktedir. Umumi kaide ve esaslar, meslektaşların hastaları ile münasebetleri, meslektaşların birbiri ile paramedikal meslek mensupları ile münasebetleri vb. konuların ${ }^{100}$ yanı sıra, hastanın hekim seçme özgürlüğü, tedaviye hekimin karar vereceği, yeni tedavi yöntemlerinin uygulanış şekilleri, hekimlerin gereken özeni göstermeleri gerektiği, hastaların hayatlarını kurtaramamaları halinde dahi ıstırap çekmelerini engellemelerinin gerektiği, durumu kötü olan hastaya üstü kapalı durumunun açıklanması gibi düzenlemeleri de içermektedir ${ }^{101}$.

\section{e. Organ ve Doku Alınması, Saklanması ve Nakli Hakkında Kanun}

1979'da 16655 sayılı R.G.'de yayımlanan 2238 Sayılı Kanun, genel hükümler, yaşayan kişilerden organ ve doku alınması ve ceza hükümleri konularını içermektedir ${ }^{102}$.

\footnotetext{
98 Köroğlu, s. 362-375; Demir (2006), s. 260-273.

99 Çınar, s. 81.

100 Köroğlu, s. 376-382; Demir (2006), s. 362-368.

101 Çınar, s. 82-89.

102 Demir (2006), s. 310-312.
} 
2238 Sayılı Kanun, organ ve doku naklinin esaslarını düzenleyerek, herhangi bir şahsın organ ve dokularının başka bir kimseye naklini yasal temellere oturtmaktadır. Getirdiği esaslar ile kişilerin eksik yahut yetersiz organları nedeniyle sağlıklı yaşamdan uzak olan hayatları, organ ve doku nakli ile sağlıklı bir hale gelebilme imkanına sahip olması nedeniyle oldukça önem arz etmektedir ${ }^{103}$.

\section{f. Sağlık Hizmetleri Temel Kanunu}

1987’de 19461 sayılı R.G.'de yayımlanan, sağlık hizmetinin eşit, kaliteli ve verimli bir şekilde sunulması amacı temelinde düzenlenen 3359 Sayılı Kanun, temel esaslar, teşkilatlanma, sağlık işletmesi, diğer personel, sözleşmeli personel, tedavi masraflarının tahsili ile ilgili düzenlemeler içermektedir ${ }^{104}$. Yıllar içerisinde değişikliğe uğrayan kanunda en son 2016'da değişiklik yapılmıştır. Milli Savunma Bakanlığı hariç, bütün kamu kurum ve kuruluşları ile özel hukuk kişilerini kapsayan kanunun önemi, sağlık hizmetine ilişkin temel kuralları yasalaştırmasıdır ${ }^{105}$.

\section{g. Hasta Hakları Yönetmeliği}

Sağlık Hizmetleri Temel Kanunu'nu dayanılarak 1998'de 23420 sayılı R.G. ile yürürlüğe giren Yönetmelik, hizmetten faydalanma hakkı, durumu ile ilgili bilgi alma hakkı, hasta haklarının korunması, hastanın rızası, tıbbi araştırmalar, sorumluluk ve hukuki korunma yollarını düzenleyerek hastaların haklarını hüküm altına almıştır ${ }^{106} .2019$ Yılı değişikliği ile Yönetmelik'in dayanağına 1 Nolu Cumhurbaşkanlığı Kararnamesi’nin 355. ve 508.maddeleri de eklenmiştir.

Hasta ile hekim arasındaki ilişkileri düzenleyen hükümler açısından Tıbbi Deontoloji Nizamnamesi'ndeki hükümlerden esinlenildiği görülmekte, bu nedenle de Hasta Hakları Yönetmeliği, Tibbi Deontoloji Nizamnamesi'nin ek yönetmeliği olarak da öğretide değerlendirilmektedir ${ }^{107}$.

\footnotetext{
103 Çınar, s. 65.

104 Temiz (2013), s. 85.

105 Demir (2006), s. 23-32.

106 Demir (2006), s. 441-453.

107 Çınar, s. 91.
} 
Hasta Hakları Yönetmeliği, hasta haklarını bir bütün olarak düzenleme altına almış olması nedeniyle oldukça önemlidir; ancak hukukun temel taşlarından biri olan hak kavramının, özellikle de hakkın ihlali halinde uygulanacak yaptırımların kanun yerine yönetmelik ile düzenlenmiş olması açısından hukuka uygun bir düzenleme olmadığı öğretide eleştirilmektedir. Öğretideki bu görüş tarafından kanunun düzenlediği çerçevede yönetmelik ile hak düzenlenebilirse de ihlali halinde uygulanacak olan yaptırımların belirlenmesi ancak ve ancak yasa ile olabileceğinin altı çizilmiştir. Bu bağlamda yaptırımdan yoksun bir düzenleme sonucunda herkesin söz konusu haktan yararlanmasının mümkün olamayacağı, dolayısıyla hakkın kullanımının sınırlanmış olacağı belirtilmektedir ${ }^{108}$. Hasta Hakları Yönetmeliği’nin dayanağı olan Sağlık Hizmetleri Temel Kanunu'nda hasta haklarının ihlali halinde uygulanacak olan yaptırımların düzenlenmediği görülmekte, söz konusu yaptırımların Yönetmelik ile düzenlendiği dikkati çekmektedir. Öğretideki görüş doğrultusunda kanaatimizce de Yönetmelik'in 46. ve 47. maddelerinde düzenlenen hasta haklarının ihlali halinde uygulanacak olan yaptırımların esasen kanun tarafından hüküm altına alınması, kanun ile düzenlendikten sonra kanunun çizdiği çerçeve içerisinde yönetmelik ile düzenlenmesi daha yerinde olacaktır.

Sağlık hakkının yalnızca bir bölümünü oluşturan hastaların haklarının bir yönetmelik ile düzenlenmesi, hastalar dışındaki diğerlerinin haklarının yönetmelikte düzenlenmemesi, hakkın bütünlüğünü bozması nedeniyle öğretide eleştirilmektedir. Bizim de katıldığımız bu görüşe göre sağlık hakkının bütünlüğünün sağlanabilmesi için sağlık alanındaki tüm ilgililerin haklarının sınırlarının belirli hale getirilebilmesi, ilişkilerin daha düzenli olabilmesi amacıyla sağlık hakkının yalnızca hastaları değil, tüm ilgilileri kapsayacak şekilde bir bütün halinde, demokratik bir ortamda, geniş bir bakış açısıyla yönetmelikle düzenlenmesi, sağlık alanında huzurlu, barış içinde ve güvenli bir ortamın oluşmasını da sağlayacaktır ${ }^{109}$.

\footnotetext{
108 Çınar, s. 91-92.
}

109 Çınar, s. 92. 


\section{h. 703 Sayılı Kanun Hükmünde Kararname (KHK)}

Sağlık alanındaki reformlarla 181, 663, 694 sayılı KHKlar ile şekillenen sağlık hizmeti idari teşkilatı, 2018'de 30473 sayılı R.G.'de yayımlanan 703 sayılı KHK ile son şeklini almıştır ${ }^{110}$.

703 Sayılı KHK.m.4’te Sağlık Bakanı'nın Sağlık Bakanlığı'nın en üst amiri olduğu, Bakanlık faaliyetleri ile Bakanlık çalışanlarının faaliyet ve işlemlerinden Cumhurbaşkanı'na karşı sorumlu olduğu düzenlenmiştir. Sağlık Bakanlığı'na bağlı Müsteşar ve Müsteşar yardımcılığı pozisyonu bu KHK ile kaldırılmış olup, Sağlık Bakanına yardımcı olması amacıyla Bakan Yardımcılığı pozisyonu düzenlenmiştir. Sağlık Bakanlığı'nın bağlı kuruluşları halen varlığını sürdürmekle birlikte, bağlı kurul niteliğindeki "Yüksek Sağlık Şurası"”nın varlığına son verilmiştir.

\section{1 Nolu ve 4 Nolu Cumhurbaşkanlığı Kararnameleri (CBK)}

2017'de 6771 Sayılı Kanun ile gerçekleştirilen anayasa değişikliğinden sonra AY.m.104'te Cumhurbaşkanı'na tanınan Cumhurbaşkanlığı Kararnamesi çıkarma yetkisi sonucunda 2018'de 30747 sayılı R.G.'de yayımlanan 1 Nolu CBK ve 30479 sayılı R.G.'de yayımlanan 4 Nolu CBK ile sağlık hizmeti idari teşkilatında değişiklik yapılmıştır. Sağlık Bakanlığı merkez teşkilatı 1 Nolu CBK'nın 12. bölümündeki 352-384. maddeleri arasında yeniden düzenlenmiş, 353-370. maddeleri arasında hizmet birimleri ve görevleri tanımlanmıştır. Aynı zamanda Cumhurbaşkanı’nın politika kurullarının başkanı olması ve böylece Sağlık ve Gıda Politikaları Kurulu aracılığıyla sağlık politikasının belirlenmesinde doğrudan söz sahibi olması hüküm altına alınmıştır. 4 Nolu CBK’nın 1. maddesinde Adli Tıp Kurumu ile giriş yapılmış, 506-519. ve 651-678. maddeleri arasında Sağlık Bakanlığı’nın bağlı

110 Yılmaztürk, Aysun (2013) “Türkiye'de Sağlık Reformlarının Tarihsel Gelişimi ve Sağlıkta Dönüşüm Programı'nın Küresel Niteliğinin Değerlendirilmesi”, Sosyal Bilimler Araştırmaları, Sa. I, C. 8, ss. 176-188, s. 186; Günaydın, Davuthan (2011) "Sağlık Hizmetlerinde Küresel Reform Yaklaşımları”, Sosyal Siyaset Konferansları, Sa. 60, C. 0, ss. 323-365, s. 323. 
kuruluşlarının yetki, görev ve sorumlulukları ile teşkilat yapısı düzenlenmiştir ${ }^{111}$.

\section{Sağlık Hakkını Koruyan ve Sağlık Hizmetinin Dayanağı Olan Başlıca İlkeler}

Sağlık hakkı ile sağlık hizmeti, yalnızca hukuki düzenlemeler ile güvence altına alınmamakta ve dayanağa kavuşmamakta, aynı zamanda birçok ilke bu görevleri desteklemekte olup, söz konusu ilkelerin çalışmamızın bu kısmında açıklanması gerekmektedir.

\section{A. Hukuk Devleti İlkesi}

Anayasa Mahkemesi kanunların, Anayasa'ya uygun olmasından önce bilinen ve tüm uygar devletlerde hâkim olan ilkelere, yani hukukun genel ilkelerine uygun olması gerektiğini belirtmiştir ${ }^{12}$. Hukukun genel ilkeleri, felsefi, ahlaki, ekonomik ve sosyolojik alanlarda toplum tarafından ortak olarak benimsenen kavramların hukuk dilindeki anlatımı olarak tanımlanabilir ${ }^{13}$. Anayasa Mahkemesi hukuk devletini, söz konusu hukukun genel ilkeleri ve hukukun üstün kuralları ile kanunların da üzerinde, kanun koyucunun da ihlal edemeyeceği temel hukuk prensiplerine bağlı, insan haklarına saygılı, hak ve özgürlükleri güçlendiren, adaletli bir hukuk düzenini sürdüren devlet şeklinde tanımlamaktadır ${ }^{114}$. Hukukun genel ilkeleri, iyi niyet, özel kural-genel kural çatışmasında özel kuralın uygulanması, ahde vefa, kesin hükme saygı, kanunların geriye yürümezliği, devlete (ve kanuna güven), kazanılmış haklara

111 Durmuş, Ayhan/Durmuş, Merve Nur (2019) “Sağlık Bakanlığı Teşkilat Yapısı”, Uluslararası Sağlık Yönetimi ve Stratejileri Araştırma, Sa. 2, C. 5, No. 2, ss. 216-229, s. 225.

112 AYM, E.1963/166, K.1964/76, K.T.22.12.1964, $<\mathrm{http}$ ///kararlaryeni.anayasa.gov.tr/Karar/Content/0c083aa1-96f0-4e67-8f676d74a867fa56? excludeGerekce=False\&wordsOnly=False>, s.e.t.17.02.2020.

113 Kaboğlu, İbrahim Ö., "Hukukun Genel İlkeleri ve Anayasa Yargısı", $<$ http://www.anayasa.gov.tr/files/pdf/ anayasa_yargisi/anyarg8/kaboglu.pdf>, s.e.t.17.02.2020, s. 291,310.

114 AYM, E.1985/31, K.1986/11, K.T.27.03.1986, <http://kararlaryeni.anayasa.gov.tr/Karar/Content/837e7b82-f11e-4ebc-b508da594476a15c?excludeGerekce=False\&wordsOnly=False $>$, s.e.t.17.02.2020. 
saygıdır ${ }^{115}$. Hukuk devletinin hukukun genel ilkelerini içermesinin ${ }^{116}$ yanı sıra, özgürlükler hukukunun eksen kavramlarını da içerdiği belirtilmektedir ${ }^{117}$.

Bireylerin özgürlügünü amaç edinen hukuk devleti ${ }^{118}$, devletin tüm faaliyetlerinde hukukun egemen olduğu devlet olarak tanımlanmaktadır. Hukuk devletinin egemen olduğu bir devlette, hukukun güvenliği ve üstünlüğünü temel alan bir düzenin kurulmasi ${ }^{119}$ ve bireylerine hukuki güvence sağlama ${ }^{120}$ esas alınmıştır.

Çağdaş demokratik ülkelerde, bazı düzenlemeler ile hukuk devleti ilkesi sisteme kazandırılmaktadır. Bu düzenlemelerin ilki, anayasanın üstün ve bağlayıcı olmasi ${ }^{121}$ ilkesi, kanunların anayasaya uygun olması ilkesi ve insan haklarının güvence altına alınması ilkesi gibi devlet faaliyetlerinin hukuka uygun olmasını sağlayan ilkeler ile kuralların benimsenmesidir ${ }^{122}$. İkinci düzenleme, devletin faaliyetlerinin hukuka uygun olmasını sağlayacak mekanizmaların getirilmesidir. Bu mekanizmalar ile idari işlemlerin kanunlara uygun olması, yasama organının işlemlerinin anayasa uygun olması sağlanacaktır. Üçüncü düzenleme ise devletin faaliyetlerinde hukuka uygun

115 Yüzbaşıŏlu, Necmi (1993) Türk Anayasa Yargısında Anayasallık Bloku, 1. Baskı, İstanbul, İstanbul Üniversitesi Hukuk Fakültesi, s. 18-24.

116 Özbudun,s. 137-138.

117 Kaboğlu, s. 314.

118 Huber, Ernst Rudolf (1970) "Modern Endüstri Toplumunda Hukuk Devleti ve Sosyal Devlet” Ankara Üniversitesi Hukuk Fakültesi, C. XXVII, Sa. 3-4, ss. 27-51, (Çeviren: Ansay, Tuğrul), s. 28; Akad, Mehmet/Vural Dinçkol, Bihterin/Bulut, Nihat (2016) Genel Kamu Hukuku, 12. Baskı, İstanbul, Der, s. 376.

119 Araslı, Utkan (2015) Anayasal Temel İlke ve Kavramlar, 1. Baskı, Ankara, Türkiye Barolar Birliği, s. 47; Öztürk, Bahri (2003) "Yaşama Hakkı Ve İşkence Yasağı (Yasak Sorgu Metodları)” İstanbul Kültür Üniversitesi Hukuk Fakültesi, C. 2, Sa. 1-2, ss. 39-80, s. 39; Erdoğan, Mustafa (2001) Türkiye'de Anayasalar ve Siyaset, 3. Baskı, Ankara, Liberte, s. $87,160-162$.

120 Demir, Fevzi (2017) Anayasa Hukuku, 10. Baskı, İzmir, Birleşik, s. 410-412; Akad/Vural Dinçkol/Bulut, s. 369; Soysal, Mümtaz (1997) 100 Soruda Anayasanın Anlamı, 11. Baskı, İstanbul, Gerçek, s. 164; Kaboğlu, İbrahim Ö. (1990) “Türkiye’de Hukuk Devletinin Gelişimi” İnsan Hakları Yıllığı, Sa. 12/1, s. 146.

121 Tanör, Bülent/Yüzbaşığlu, Necmi (2016) 1982 Anayasasına Göre Türk Anayasa Hukuku, İstanbul, Beta, s. 108.

122 Araslı, s. 47; Öztürk, s. 39-40. 
hareket etmesini sağlayacak olan yargı erkinin devletin diğer erklerinden bağımsız olmasının sağlanmasıdır ${ }^{123}$. Öğretide hukuk devletinin adaletin sağlanması, güvenliğin oluşturulması ve insan haklarının korunması şeklinde üç temel unsur üzerine yerleştiği şeklinde düşünülmektedir ${ }^{124}$.

Türkler'in Magna Carta'sı olarak nitelendirilen 1808'de imzalanan Sened-i İttifak, Türkiye'de hukuk devletine dair ilk atılan adımdır ${ }^{125} .1921$ ve 1924 Anayasaları'nda ancak bağımsız, ulusal ve laik bir devletin kurulmasını içeren hükümlerin anayasada düzenlenebilmesi ${ }^{126}$ nedeniyle henüz hukuk devleti ilkesi gündeme gelebilecek durumda değildi ${ }^{127} .1921$ Anayasası, "egemenliğin kayıtsız, şartsız millete ait olduğu"nu düzenlemesi ${ }^{128}, 1924$ Anayasası'nda vatandaşların haklarının devlet tarafından verilmediği, aksine bireylerin bu haklara doğuştan sahip olduğu anlamına gelen "doğal haklar ilkesi ${ }^{129 "}$ "nin benimsenmesi hukuk devletinin yerleşmesi bakımından önem arz etmektedir ${ }^{130} .1961$ Anayasası'nda, hukuk devleti ilkesi açıkça düzenlenerek, anayasanın değiştirilemeyecek hükümleri arasında yer almıştır, hukuk devleti ilkesi kuvvetli bir şekilde vurgulanmıştır ${ }^{131}$. 1982 Anayasası ise T.C.'nin bir hukuk devleti olduğunu 2. maddesinde belirterek düzenlemiş olsa da devletin bazı faaliyetlerini hukuk denetimi dişında bırakması nedeniyle hukuk devleti ilkesini zayıflattığg yönünde öğretide eleştirilmektedir ${ }^{132}$.

123 Uygun, Oktay (2013) Kamu Hukuku İncelemeleri, 2. Baskı, İstanbul, On İki Levha, s. 388389; Soysal, s. 164-165; Özbudun, s. 126-139; Kaboğlu (1990), s. 143-144; Erdoğan (2001), s. 162.

124 Demren Dönmez, Burcu (2012) “Ayrımcllık Suçu” Türkiye Barolar Birliği, Sa. 102, ss. 9-58, s. 14.

125 Demir, Fevzi/Bakıcı, Zeynel/Çınarlı, Serkan (2011) Etkin Demokratik Hukuk Devleti, 1. Baskı, Ankara, Orion, s. 17; Kaboğlu (1990), s. 139.

126 Uygun, s. 391.

127 Tanör/Yüzbaşığlu, s. 108.

128 Demir/Bakıcı/Çınarlı, s. 121.

129 Shestack, Jerome J. (2006) “İnsan Haklarının Felsefi Temelleri” Liberal Düşünce, C. 11, No. 43, ss. 87-119, s. 92-94.

130 Uygun, s. 392; Kaboğlu (1990), s. 155-157.

131 Kaboğlu (1990), s. 158-161.

132 Uygun, s. 395; Kaboğlu (1990), s. 161-164. 
AYM'nin 1963'te vermiş olduğu bir kararında ${ }^{133}$ hukuk devleti yalnızca şekli olarak değil maddi olarak da tanımlanmıştır. Devletin faaliyetlerinin hukuk kurallarına uygun olması ile birlikte, hukuk kurallarının da insan haklarını koruyan, adil ve temel hukuk kurallarına uyan nitelikte olması gerekmektedir. Kararda, hukuk devleti ilkesinin içeriği hem anayasa hem de anayasanın ötesindeki ilkelerle somut hale getirilmiştir. İnsan hakları ile anayasaya saygı, adalet, eşitlik ve yargı denetimi anayasanın metninden ortaya çıkan prensiplerdir.

Temel hak ve özgürlüklerden biri olan sağlık hakk $1^{134}$ da ancak ve ancak hukuk devleti ilkesinin benimsenmesi ile vatandaşlara tanınabilir. Kaldı ki devletin sağlık hakkından bireylerin yararlanmasına yönelik yapmış olduğu faaliyetlerden olan sağlık hizmeti de ancak hukuk devleti ilkesinin benimsenmesi ile uygulamaya geçen denetim mekanizmaları ile hukuka uygun bir şekilde yerine getirilebilir. Hukuk devleti ilkesi, AYM'nin de kararından anlaşılacağı üzere diğer tüm ilkelerin temelindeki ilkedir. Sağlık hakkının korunmasına ilişkin diğer ilkeler olan sosyal devlet, insan onurunun korunması, eşitlik ve özel hayatın gizliliği ilkeleri ancak bir ülkede hukuk devleti ilkesi hakim ise söz konusu olabilecektir. Bu bağlamda hukuk devleti ilkesi sağlık hakkının korunması ile sağlık hizmetinin dayanağının oluşturulması açısından büyük önem taşıyan, en temelde yer alan ilkedir.

\section{B. Sosyal Devlet İlkesi}

Kökleri 19. yüzyıla uzanan; fakat 20. yüzyılın ürünü olan ${ }^{135}$ sosyal devlet, vatandaşlarına asgari düzeyde yaşam sağlamay $1^{136}$, vergi adaletini,

\footnotetext{
133 AYM,

E.1963/124,

K.1963/243,

K.T.11/10/1963,

<http://kararlaryeni.anayasa.gov.tr/Karar/Content/eb2d4895-

a40f-44ee-8492-831a8d126401? excludeGerekce=False\&wordsOnly=False>, s.e.t.17.02.2020.

134 Temiz (2013), s. 135-136; Temiz (2014), s. 172.

135 Tanör/Yüzbaşığlu, s. 104.

136 Balkır, Zehra Gönül (2009) Türk Anayasa Yargısında Sosyal Hakların Korunması, 1. Baskı, Kocaeli, Kocaeli Üniversitesi Yayınları Yayın No. 335, s. 48; Polatcan, İsmet (1989) Türkiye Cumhuriyeti Anayasası, Gerekçeler, Anayasa Mahkemesi Kararları, Bilimsel Görüşler, 1. Baskı, İstanbul, Bayrak, s. 35; Duman, İlker Hasan (1997) Sosyal Devlet, 1. Baskı, İstanbul, İnkilap, s. 32.
} 
kamulaştırma ve devletleştirmeyi, planlama ile sosyal hakların bireylerce kullanılmasını hedefleyen ${ }^{137}$, onların refahı ve sosyal durumlarıla ilgilenen devlet olarak tanımlanmaktadır ${ }^{138}$. Sosyal adalet, sosyal refah ve sosyal güvenlik ilkelerini ${ }^{139}$ dayanak alan devlet şekli yahut ekonomik ve sosyal açıdan zayıfları koruyan devlet şekli olarak da öğretide sosyal devleti tanımlayanlar ${ }^{140}$ mevcuttur. Sosyal devlet başka bir tanımla, devletin tüm eylem ve işlemlerinde kamu yararını göz önünde bulundurarak hareket etmesidir ${ }^{141}$. Sosyal devlet ilkesini benimsemiş yönetimlerde devlet, hem kendisi bireylerin hak ve özgürlüklerine müdahale etmeyecek hem de başkalarının da bireylerin hak ve özgürlüklerine müdahale etmesini engelleyecek ve hak ile özgürlüklerin kullanılmasını önleyen tüm engelleri kaldıracaktır ${ }^{142}$. Bu anayasal yükümlülükleri devlete veren sosyal devlet ilkesi, hukuk devletinin ileri bir aşaması olmasının yanı sıra, varmış olduğu çağdaş bir düzen olarak da nitelendirilmektedir ${ }^{143}$. Temel amacı herkesin iyiliğini sağlamak olan sosyal devlet ilkesini ${ }^{144}$ benimsemiş devletler, toplumda var olan eşitsizlikleri gidermek suretiyle, bireyin eğitimi, ailesinin korunması, iş bulması, sağlığı ve konutu gibi alanlarda geniş görevler alarak ${ }^{145}$ vatandaşlarına insan onuruna uygun bir yaşam seviyesini sunmayı da amaçlamaktadır ${ }^{146}$.

Demokratik ülkelerce benimsenmiş olan hukuk devletinin de bir gereği sosyal devlet anlayış1 1961 Anayasası'nın 2. maddesinde “Türkiye Cumhuriyeti, insan haklarına ve başlangıçta belirtilen temel ilkelere dayanan, millî demokratik, lâik ve sosyal bir hukuk Devletidir." ifadesi ile anayasalarımıza

137 Özbudun, s. 147-156; Gözler, Kemal (2012) Kısa Anayasa Hukuku, 7. Baskı, Bursa, Ekin, s. 154-155; Erdoğan (2001), s. 158; Tanilli, Server (2007) Devlet ve Demokrasi: Anayasa Hukukuna Giriş, 4. Baskı, İstanbul, Alkım, s. 147.

138 Erdoğan (2001), s. 159.

139 Polatcan, s. 35.

140 Tanör/Yüzbaşığlu, s. 106.

141 Balkır, s. 47.

142 Demir (2017), s. 353; Tanilli, s. 147-148.

143 Özay, İl Han (2002) Günışığında Yönetim, İstanbul, Alfa, s. 76.

144 Huber, s. 28; Akad/Vural Dinçkol/Bulut, s. 376.

145 Arasli, s. 99.

146 Sabuncu, Yavuz (2007) Anayasaya Giriş Ek: 1982 Anayasası, 13. Baskı, Ankara, İmaj, s. 151,153; Temiz (2014), s. 176. 
girmiş, 1982 Anayasası'nda da yine 2. maddede “Türkiye Cumhuriyeti, toplumun huzuru, milli dayanışma ve adalet anlayışı içinde, insan haklarına saygıll, Atatürk milliyetçiliğine bağlı, başlangıçta belirtilen temel ilkelere dayanan, demokratik, laik ve sosyal bir hukuk Devletidir." şeklinde yerini korumuştur.

İkinci Dünya Savaşı'nın ardından batı demokrasilerinde sosyal devlet anlayışının benimsenmesiyle anayasalara sosyal ve ekonomik haklar girmiştir. Sosyal devlet anlayışında devlet, sosyal hakları bir iktisadi öğreti olarak görmenin aksine, bu hakları hümanizm ve adalet duygusunun ürünü sayarak şans ve olanak eşitliği içerisinde tüm bireylere uygulanmasını sağlar ${ }^{147}$. Sosyal haklardan biri olan sağlık hakk1 ${ }^{148}$ gereğince herkesin beden ve ruh sağlığı içinde yaşama hakkı, sağlık koşullarına uygun meskenlerde barınma hakkı ile gelecek ve yoksulluk korkusundan kurtulma hakkı bulunmaktadır. Devlet kişilerin bugünü ve yarınını kurtaracak, koruyup güvence altına alacak, herkesin sağlık koşullarına uygun meskenlerde barınmalarını sağlayacaktır ${ }^{149}$.

Bireyin sağlıklı ve onurlu bir yaşam sürmesi adına sağlık hizmetinden olabildiğince eşit ve adil bir şekilde yararlanmasında sosyal devlet ilkesinin önemi yadsınamaz bir gerçektir. Sosyal devlet ilkesinin uygulanması ile sağlık hakkı da koruma altına alınmış olacak ve bireyler bu haktan tam anlamıyla yararlanabileceklerdir ${ }^{150}$. Özel hastane kamu hastanesi fark etmeksizin acil serviste ücret alınmadan hastaların tıbbi müdahale ile tedavi edilmesi bu ilkenin getirdiği bir uygulamadır ${ }^{151}$. Kanaatimizce acil bir müdahale gerekmesi halinde bireyin parasının olup olmaması önem taşımamalı, önemli olan bireyin ruh ve beden sağlığının tam olarak sağlanması olmalıdır. Devlet, sosyal devlet ilkesi

147 Duman, s. 23-24.

148 Temiz (2013), s.4; Temiz (2014), s. 168,185.

149 Göze, Ayferi (2005) Liberal Marxiste Faşist ve Sosyal Devlet, 4. Baskı, İstanbul, Beta, s. 150152; Göze, Ayferi (2015) Siyasal Düşünceler ve Yönetimler, 15. Baskı, İstanbul, Beta, s. 408410.

150 Çınar, s. 18.

151 Kalemoğlu, Murat, (2005) “Acil Serviste Hekim Sorumluluğu” Türkiye Klinikleri Tıp Bilimleri, C. 25, Sa. 6, ss. 824-828, s. 826. 
gereğince kişilerin maddi durumunu gözetmeksizin sağlık hakkından yararlanmalarına yönelik gereken her imkanı tanımalıdır.

Sağlıklı yaşamın gerçekleştirilebilmesi için sosyal devlet ilkesi çerçevesinde devlet tarafından sağlık hakkının yanı sıra, barınma, beslenme, eğitim, çalışma ve hatta sosyal güvenlik gibi hakların da bireye sunulması ve bu hakların bir bütün halinde uygulanması yönünde de çalışmalar yapılması gerekmektedir ${ }^{152}$.Anayasa'nın 2. maddesinin gerekçesinde de bu hususa yer verilerek, “...Modern Anayasa, asgari geçim şartlarından, sihhi bakımdan, öğrenim imkanlarından ve hele barınacağı bir konuttan yoksun bir kişinin gerçek anlamda hür olamayacağını kabul eden zamanımızın hukuk ve siyaset ilmine ve devlet görüşüne uygun olarak fertlere ve vatandaşlara sosyal birtakım haklar tanımak zorundadır...” ifadeleriyle sağlık bakımından vatandaşlara haklar tanınmasının yanı sıra, diğer alanlarda da devletin yükümlülükleri açıkça belirtilmiştir. $\mathrm{Bu}$ bağlamda sosyal devlet ilkesi tüm ilke ve kurumlarıyla uygulanmadıkça, aynı zamanda sağlı hakkı da diğer haklarla desteklenmedikçe bireyler sağlıklı yaşama hakkına kavuşamayacaktır. Devlet, sosyal devlet ilkesinin tüm gereklerine uygun bir şekilde hareket etmeli, bireyin ve dolayısıyla toplumun sağlık hakkı ile diğer haklara kavuşmasını sağlamalı, sağlık hizmetini gereği gibi yerine getirmelidir. Keza AYM'nin de bu yönde kararlar1 ${ }^{153}$ bulunmaktadır.

152 Bayraktar, Köksal (1972) Hekimin Tedavi Nedeniyle Cezai Sorumluluğu, İstanbul, İstanbul Üniversitesi Yayınları No. 768, Hukuk Fakültesi Yayınları No. 391, Sermet Matbaası, s. 18.

153 Nitekim AYM'nin bu konuya ilişkin bir kararına bkz.: “...Anayasa, sosyal hukuk devleti olmanın gereği olarak Devlete sağlık hizmetlerinin sunumunda pozitif yükümlülük yüklemiş, Devleti bu haklardan yararlanmayı artıracak önlemleri almakla mükellef kılmıştır. Bu nedenle Anayasa'nın 56. maddesinde öngörülen sağlık hakkından yararlanma konusunda en geniş ölçekli uygulamaların gerçekleştirilmesi gerekir. Sağlık hizmeti sunumunun diğer hizmetlerden farklı olduğu açıtıtı...” AYM, E.2014/61, K.2014/166, K.T.07.11.2014, 29391 Sayılı R.G., Y.T.19.06.2015. 


\section{C. İnsan Onurunun Korunması İlkesi ve İşsence Yasağı}

\section{1. İnsan Onuru Kavramı}

Öğretide hem hak yaratıcı hem de yorumlayıcı bir kavram olarak ele alınan $^{154}$ insan onuruna dair ilk açıklamayı yapan Cicero, bireyin insan olmaktan doğan öz değerini açıklamaktansa bireyin toplum içindeki değerini, sosyal statüsünü ve yükümlülüklerini ifade etmektedir. "İnsan değeri” her durumda saygının varlığının gerektiğini, insani öz anlamına geldiğini, tüm insanların onur bakımından eşit olduğunu vurgulamaktadır ${ }^{155}$. Öğretide Bavyera Anayasa Mahkemesi'nin 1948'deki “insanın kişi olarak en yüksek ahlaki ve akli değerleri ile birlikte dokunulmaz, kaybedilmez bir öz değerin de sahibi olması" şeklinde insan onurunu tanımlayan kararını destekleyen görüşler mevcuttur ${ }^{156}$. İnsan onurunun bünyesinde saygı, aydınlanma, güç, iyi hal, yetenek, sevgi, dürüstlük ve sağlık şeklinde sekiz değeri barındırdığı da öğretide belirtilmiştiri ${ }^{157}$.

İnsanın salt insan olması nedeniyle değerli ve saygıya layık bir varlık olması şeklinde de tanımlanan ${ }^{158}$ insan onuru kavramı, Türk anayasalarında

154 Barroso, Luis Roberto (2012) "Here, There and Everywhere: Human Dignity in Contemporary Law and in the Transnational Discourse", Boston College International and Comparative Law Review, Volume 35, Issue 2, Article 2, $<$ http://lawdigitalcommons.bc.edu/iclr/vol35/iss2/2>, s.e.t.17.02.2020.

155 Uygun, s. 46.

156 Bulut, Nihat (2008) “Eski Yunan'dan Aydınlanma Çağı'na İnsan Onuru Kavramının Gelişimine Bir Bakış” Erzincan Üniversitesi Hukuk Fakültesi, C. XII, Sa. 3-4, ss. 1-12, s. 2; Şimşek, Oğuz (1999) “Anayasa Hukukunda İnsan Onuru Kavramı ve Korunması” (Doktora), Dokuz Eylül Üniversitesi Sosyal Bilimler Enstitüsü, s. 65; Arslan, Kahan Onur (2015) "İnsan Onuru Kavramı ve Koruma Tedbirleri Bağlamında Temel Bir İlke Olarak İnsan Onurunun Korunması” Türkiye Barolar Birliği, Sa. 120, ss. 155-172, s. 156; Aldanmaz, Orhan (2010) "İnsan Onuru Işs̆ğında Kişisel Özerklik ve Yerellik İlkesi” Erzincan Üniversitesi Hukuk Fakültesi, C. XIV, Sa. 1-2, ss. 79-109, s. 84.

157 Mcdougal, S. Myres/Chen, Lung-chu/Lasswell, Harold D., (1977) "Human Rights in World Public Order: Human Rights in Comprehensive Context”, Yale Law School Faculty Scholarship Series, Paper 2665, Yale,

<http://digitalcommons.law.yale.edu/fss_papers/2665>, s.e.t.17.02.2020, s. 231-236; Shestack, s. 111.

158 Seymen Çakar, Ayșen (2013) "Hukuki Bir Kavram Olarak İnsan Onuru” Umut Vakfı Araştırma Merkezi 3. Hukukun Gençleri Sempozyumu, Antalya, ss. 1-8, s. 1-3; Arslan, s. 157. 
temel bir hak olarak görülüp doğrudan bir hükümle koruma altına alınmamasına rağmen, “...onurlu bir yaşam sürdürme ve maddi ve manevi varlığını bu yönde geliştirme hakkı...” şeklinde Anayasa'nın başlangıç kısmında yer alan ifadeler ve AY.m.13'te bulunan “... Temel hak ve hürriyetler, özlerine dokunulmaksızın yalnıza anayasanın ilgili maddelerinde belirtilen sebeplere bağlı olarak ve ancak kanunla sinırlanabilir. Bu sınırlamalar, Anayasa'nın sözüne ve ruhuna, demokratik toplum düzeninin ve laik Cumhuriyetin gereklerine ve ölçülülük ilkesine aykırı olamaz.” düzenlemeleri gereği, Türk Anayasa sisteminde önemli rol oynamaktadır. Kaldı ki insan onuru, yalnızca başlangıcın 8. paragrafı ile değil, diğer temel haklar ile de koruma altına alınmıştır. 1982 Anayasası'nda düzenlenen bütün temel haklar insan onurundan kaynaklanmakta olup, insan onuru gereğince gerekli görüldüğü için düzenlenen, insan onurunun bağımsızlaşmış parçaları özelliğini göstermektedir ${ }^{159}$.

Akıllı bir varlık olan insanın özgür bir şekilde ahlaki davranarak oluşturduğu insan onuruna ${ }^{160}$ dair sağlık hakkı ve sağlık hizmeti bağlamında birçok uluslararası belge bulunmaktadır. 1999'da yürürlüğe giren Biyoloji ve Tıbbın Uygulanması Bakımından İnsan Haklarının ve İnsan Haysiyetinin Korunması Sözleşmesi bir sözleşme olup, taraf devletlere yükümlülükler yüklemektedir ${ }^{161}$. Biyoetik konusunu insan hakları çerçevesine oturtan ilk bağlayıcı belge niteliğini taşıyan bu Sözleşme, insan kimliği ile onuruna hayat başlar başlamaz saygı gösterilmesi gerektiğini ilke edinmiştir. 1997'de UNESCO tarafından yayınlanan İnsan Genomu ve İnsan Hakları Evrensel Bildirisi'nde biyoloji, genetik ve tıp alanlarında hiçbir araştırma yahut araştırmanın ardından yapılan uygulamanın insan onurunu ihlal edemeyeceği belirtilmiştir. UNESCO’nun 2005'te kabul ettiği Biyoetik ve İnsan Hakları

159 Önok, Murat (2006) Uluslararası Boyutuyla İşkence Suçu, 1. Baskı, Ankara, Seçkin, s. 351; Gören, Zafer (1993) Temel Hak Genel Teorisi, 2. Baskı, İzmir, Cumhuriyet, s. 128; Şimşek, s. 251; Erdem, Mustafa Ruhan (2001) Ceza Muhakemesinde Organize Suçlulukla Mücadelede Gizli Soruşturma Tedbirleri, 1. Baskı, Ankara, Seçkin, s. 240.

160 Heinzmann, Richard (2010) "İnsan ve İnsan Onuru-Toplumsal Yaşam İçin Etik ve Ahlak", ss. $\quad 53-65, \quad<$ http://www.konrad.org.tr/Islam\%20tr\%202006/07heinzmanTR.pdf >, s.e.t.17.02.2020, s. 61 .

161 Temiz (2013), s. 81-83. 
Evrensel Bildirisi'nde tüm insanların onur ve haklarının eşit olduğu ve tüm insanlara adil ve hakkaniyete uygun olarak davranılması gerektiği vurgulanmıştır. 1997'de yayımlanan Şimdiki Nesillerin Gelecek Nesillere Yönelik Sorumlulukları Bildirisi'nde, insan onurunu ihlal etmeden insan genomu ile biyoçeşitliliğin koruma altına alınması gerektiği belirtilmiştir ${ }^{162}$.

Sağlık hakkının gereği olarak bireyler sağlık hizmetinden yararlanırken, bireylere tıbbi müdahaleler uygulanırken insan onuruna aykırı hareket edilmemesi, söz konusu ilkenin ihlali niteliğinde olabilecek davranışlardan, müdahalelerden kaçınılması gerekmekte, bu nedenle bu ilke sağlık hakkının korunması için önem taşımaktadır.

\section{2. İşkence Yasağı}

İşkence yasağı birçok uluslararası belgede düzenlenmiş olup ${ }^{163}$, özellikle AİHS.m.3'te "Hiç kimse işkenceye, insanlık dişı ya da aşağılayıcı muamele veya cezaya tabi tutulamaz." ifadeleri ile hüküm altına alınmış, yasak kapsamında işkence, insanlık dışı ve aşağılayıcı muamele ve cezaların yasak olduğu belirtilmiştir. Kişinin fiziksel bütünlüğü ile birlikte onurunu koruyan bu yasaklar mutlak olup, kişinin işlediği suçun önemine bakılmaksızın bu tip muamele ve cezalara tabi tutulması hiçbir zaman söz konusu olamaz ${ }^{164}$. AY.m.17'de ise "Herkes, yaşama, maddi ve manevi varliğını koruma ve geliştirme hakkına sahiptir. Tibbi zorunluluklar ve kanunda yazılı haller dışında, kişinin vücut bütünlüğüne dokunulamaz; rızası olmadan bilimsel ve tıbbi deneylere tabi tutulamaz. Kimseye işkence ve eziyet yapılamaz; kimse insan haysiyetiyle bağdaşmayan bir cezaya veya muameleye tabi tutulamaz..." ifadeleri ile işkence, eziyet ve insan haysiyeti ile bağdaşmayan muamele ve cezaların yasak olduğu düzenlenmiştir. Yaşama hakkının bir sonucu olarak

162 Gürbüz, Nagehan (2014) Biyotıp Hukukunda İnsan Onuru, 1. Baskı, İstanbul, On İki Levha, s. 28-36.

163 Döner, s. 53 vd.; Demirbaş, Timur (2016) İşkence Suçu, 2. Baskı, Ankara, Seçkin, s. 41-48; Gemalmaz, s. 795-929.

164 Güntürk, Mümin Serdar (2012) Özel Hayatın Gizliliğinin Korunması, 1. Baskı, Ankara, Seçkin, s. 34. 
görülen vücut bütünlüğünü koruma hakkına aykırı davranışlar ${ }^{165}$, AY.m.17/3'te açıkça yasaklanmıştır. Vücut bütünlüğünü koruma hakkı, AİHS.m.3’te düzenlendiği gibi mutlak bir haktır; ancak vücut bütünlüğüne dokunulma yasağının AY.m.17/2'de açıkça ifade edildiği üzere "tıbbi zorunluluk" ve "kanunda yazılı haller" olmak üzere iki istisnası bulunmaktadır ${ }^{166}$. Vücut bütünlüğü ile kastedilen, hem maddi yani fiziksel, biyolojik varlık hem de manevi varlık yani akıl ve ruh sağlığıdır ${ }^{167}$. Kişi bütünlüğü ile kastedilen, beden ve ruhsal sağlığının yanı sıra, hayat varlığının haricinde olan ve kişinin maddi varlığı kapsamında bulunan güzellik gibi her türlü değerler bütünüdür ${ }^{168}$. İşkence yasağ 1 ile korunmak istenen, işkenceye uğrayan kişinin ruh ve beden bütünlüğü ile onuru, yaşama hakkıdır ${ }^{169}$. Kaldı ki işkence suç olarak, TCK.m.94'te hüküm altına alınmış ve bu suçun gerçekleşmesi halinde uygulanacak cezalar da ilgili maddede düzenlenmiştir. Çalışmamızın konusu olan sağlık hakkı gereği icra edilen sağlık hizmetinin kapsamında bulunan tıbbi müdahaleler istisnaya dahil olmaktadır; ancak belirtilmelidir ki kişinin rızasıyla tıbbi müdahale yahut deney yapılsa dahi yapılan bu müdahaleler, yaşama ve vücut bütünlüğünü koruma hakkını tehlikeye düşürebilecek özellik arz etmemelidir. Kişi, yaşama hakkı ile vücut bütünlüğünü ihlal eden fiiller için ancak hukuk düzeninin izin verdiği konularda izin verebilir. Kişinin rızası olmadan kişiye tıbbi müdahale yapılabilmesinin de tek şartı ancak ve ancak

165 Gökcan, Hasan Tahsin (2017) Tıbbi Müdahaleden Doğan Hukuki ve Cezai Sorumluluk, 3. Baskı, Ankara, Seçkin, s. 47.

166 Doğru, Osman (2010) Anayasa ile Karşılaştırmalı İnsan Hakları Avrupa Sözleşmesi ve Mahkeme İçtüzüğü, 1. Baskı, İstanbul, On İki Levha, s. 8.

167 Nuhoğlu, Ayşe (1999) “İşkence Yasağı ve İşkence Suçu” Prof.Dr.Sahir Erman'a Armağan İstanbul Üniversitesi Hukuk Fakültesi Eğitim Öğretim ve Yardımlaşma Vakfı Yayın No. 8, İstanbul, s. 555; Üzülmez, İlhan (2003) Türk Ceza Hukukunda İşkence Suçu, 1. Baskı, Ankara, Turhan, s. 66-67; Önok, s. 354.

168 Toroslu, Nevzat (1970) Cürümlerin Tasnifi Bakımından Suçun Hukuki Konusu, Ankara, Sevinç, s. 320; Artuk, Mehmet Emin/Gökcen, Ahmet/Yenidünya, A. Caner (2006) Ceza Hukuku Özel Hükümler, 7. Baskı, Ankara, Turhan, s. 104; Önok, s. 354.

169 Demirbaş, s. 82; Artuk/Gökcen/Yenidünya, s. 105; Koca, Mahmut/Üzülmez, İlhan (2015) Türk Ceza Hukuku Özel Hükümler, 2. Bask1, Ankara, Adalet, s. 244; Tezcan, Durmuş/Erdem, Mustafa Ruhan/Önok, Murat (2016) Teorik ve Pratik Ceza Özel Hukuku, 13. Baskı, Ankara, Seçkin, s. 269-270. 
yaşamının ve vücut bütünlüğünün tehlikede olması ve bilincinin de yerinde olmamasidır ${ }^{170}$.

1987’de yürürlüğe giren Birleşmiş Milletler İşkenceye Karşı Sözleşme işkencenin tanımı açısından önem teşkil etmektedir. AİHM de kararlarında bu Sözleşme'deki tanımı benimsemiştir. Bu tanıma göre işkence, "İkrar veya bilgi elde etmek, işlenmiş veya işlendiğinden şüphelenilen bir fiil nedeniyle cezalandırmak, gözdă̆ vermek veya zorlamak amacıyla veya ayrımcilı̆̆a dayanan herhangi bir gerekçeyle, bir kamu görevlisi veya resmi sifatla hareket eden bir kişi tarafindan veya bu kişilerin teşviki veya rızası veya muvafakatiyle üçüncü kişi tarafindan, kasten işlenen ve işlendiği kimseye fiziksel veya ruhsal olarak ağır acı veya ıstırap veren herhangi bir fiildir." Sözleşme ve bildirilerdeki tanımlar ile öğretideki tanımları toparlarsak oluşan bir tanım da, "Bir kamu görevlisi veya onun nüfuzu, teşviki veya hoşgörüsünün himayesi altında hareket eden bir şahıs tarafindan, mağduru adli kovuşturmayla ilgili olarak belirli bir şekilde davranmaya zorlamak ya da işlediği veyahut işlediğinden şüphe edilen bir fiil ya da herhangi temel dayalı ayrmmcilı sebebiyle cezalandirmak saikiyle işlenip kişide fiziksel ya da psikolojik olarak yoğun acı veya ıstırap doğurarak ya da herhangi bir şekilde insan onuruna ağır bir saldırı teşkil ederek onun manevi

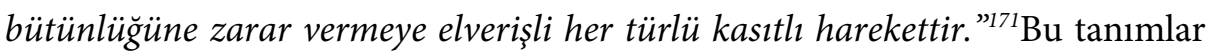
ışığında işkence üç unsurdan oluşmaktadır. İlk unsur çekilen acının yoğunluğu, ikinci unsur kast ve son unsur ise özel bir amacın varlığıdır. AİHM işkence ile diğer yasaklı muameleleri ayırt etmek için amaç unsuruna dikkat etmektedir ${ }^{172}$.

İşkencenin unsurlarını taşımasa da asgari bir ağırlık seviyesine ulaşan ${ }^{173}$ muamele, insanlık dışı veya aşağılayıcı muamele yahut ceza olarak nitelendirilir ${ }^{174}$. Bu kavramlar, işkencenin gölgesinde kalmaması maksadıyla

170 Gökcan, s. 47.

171 Önok, s. 33.

172 Demirbaş, s. 55; Tezcan/Erdem/Sancakdar ve Diğerleri, s. 136; Anayurt, Ömer, (2008) “Avrupa İnsan Hakları Mahkemesi İçtihatlarında İşkence Kavramı” Gazi Üniversitesi Hukuk Fakültesi, C. II, Sa. 1-2, ss. 421-459, s. 425, 431; Akgül, Aydın (2014) "İşkence Nedeniyle Açılan Tam Yargı Davalarında Danıştay Ölçütleri” Türkiye Barolar Birliği, Sa. 112, ss. 189236, s. 201.

173 Anayurt, s. 425; Öztürk, s. 41.

174 Doğru, s. 8-9. 
Birleşmiş Milletler İşkencenin Önlenmesine İlişkin Sözleşme'de, “diğer işkence biçimleri” olarak adlandırılmıştır ${ }^{175}$. Hareketin nitelik farkına göre değil, yoğunluk farkına göre ${ }^{176}$ ayrım yapıldığı ve farklı isimlerle adlandırıldığı görülmektedir ${ }^{177}$. Alçaltıcı veya kötü muamele, mağdurda korku, acizlik veya değersizlik duygusunu ortaya çıkaran, mağduru büyük ölçüde utandıran, rezil eden muamele anlamına gelirken, insanlık dışı muamele, bedensel yahut ruhsal açıdan şiddetli acı, eza yaratan kasti muameledir ${ }^{178}$.

AİHS'te en hafif muamele alçaltıcı ve kötü muamele iken orta ağırlıktaki muamele insanlık dışı muamele, en ağır olan muamele ise işkence olup, üç kavram kademeli olarak düzenlenmiştir ${ }^{179}$. Her işkence, insanlık dışı muamele yahut onur kırıcı muamele olabilir; ancak her onur kırıcı muamele insanlık dışı muamele ya da işkence değildir ${ }^{180}$. Durumun özellikleri, gerçekleştiği ortam, kişinin davranışının niteliği, fiziksel yahut ruhsal etkileri, süresi, mağdurun cinsiyeti, yaşı, sağlık durumu ve olayın kişi üzerinde devam etmekte olan etkisi gibi ölçütler asgari eşik olarak nitelendirilir ve muamelenin ağırlığının belirlenmesinde dikkate alınır ${ }^{181}$.

AİHS m.3'e göre devlet yetkilileri üç tür yükümlülüğü haizdir. İlki negatif yükümlülük olarak işkence ve kötü muamele yapılmaması, ikincisi pozitif yükümlülük olarak kişileri işkence ve kötü muameleye karşı koruma, üçüncüsü ise yine bir pozitif yükümlülük olarak herhangi bir işkence yahut kötü muamele olması halinde soruşturmanın yapılmasıdır. Devletin bireyi aile içi şiddet dâhil olmak üzere üçüncü kişilerin ruhsal veya fiziksel her türlü yaralama, cinsel istismar veya saldırılarına karşı koruması, nezarethanede, ceza evinde,

Anayurt, s. 426.

176 Demirbaş, s. 56.

177 İnceoğlu, Sibel/Boyar, Oya/Karan, Ulaş/Akbulut, Olgun/Arslan Öncü, Gülay/Tokuzlu, Lami Bertan (2013) İnsan Hakları Avrupa Sözleşmesi ve Anayasa, 3. Baskı, İstanbul, Beta, s. 138; Önok, s. 172, Gözübüyük/Gölcüklü, s. 214.

178 Tezcan/Erdem/Sancakdar ve Diğerleri, s. 135; Önok, s. 170-171.

179 Tezcan/Erdem/Sancakdar ve Diğerleri, s. 135; Önok, s. 172.

180 Gözübüyük/Gölcüklü, s. 214.

181 Gözübüyük/Gölcüklü, s. 214; Tezcan/Erdem/Sancakdar ve Diğerleri, s. 134; Demirbaş, s. 57. 
yabancıları tutma merkezlerinde ${ }^{182}$ bu tip davranışlara karşı kişileri koruması bu yükümlülüklerine örnek olarak verilebilir. Bir diğer önemli örnek ise konumuz açısından büyük öneme sahip olan sağlık hakkını kullanarak her türlü hastanede sağlık hizmetlerinden yararlanan hastanın kasten yahut ihmalle ruhsal ve fiziksel acı çekmelerinin devlet tarafından önüne geçilmesi gerekliliğidir. Bu nedenle işkence yasağı ilkesi de sağlık hakkının korunması ve sağlık hizmetinin hukuki temellerinin kurulması açısından büyük öneme sahip olan bir ilkedir.

\section{Ç. Eşitlik İlkesi ve Ayrımcılık Yasağı}

\section{Eşitlik Kavramı}

Eşitliği tanımlamak için Aristotales, John Locke, Herakleitos, Rousseuo, Sokrates, Kant, Marx gibi Avrupalı düşünürlerin tanımlar1 ${ }^{183}$ bulunmasının yanı sıra, eşitlik kavramı toplumdan topluma değişiklik göstermektedir. Kimi toplumda tüm vatandaşlar arasında tam eşitlik kimi toplumda ise kişi yahut azınlık grubunun temel alınarak diğerlerinden üstün tutulduğu, bu kişiler dışında kalan çoğunluk arası eşitlik sağlandığı görülmüştür ${ }^{184}$. Modern eşitlik kavramı ise "kanun önünde eşitlik”"185 "bütün insanların eşit işlem görmeye hakkı olduğu" ve bu sayede "insanlara eşit işlem yapılması gerekliliğì" anlamına gelen "Bütün insanlar eşittir.” yahut "Bütün insanlar eşit onur ve değerdedir." şeklinde tanımlanabilirr ${ }^{186}$. Eşitlik, benzer durumdaki gerçek kişi yahut tüzel kişilerden bir bölümüne daha çok veya geniş hak ile yetkilerin tanınmaması

182 Doğru, s. 9-10.

183 Kapani, Münci (2013) Kamu Hürriyetleri, 7. Baskı, Ankara, Yetkin, s. 32; Şenel, Alaeddin (1970) Eski Yunanda Eşitlik ve Eşitsizlik Üstüne, 1. Baskı, Ankara, Sevinç, s. 149, 375; Uygun, s. 47-48; Turner, Bryan (2013) Eşitlik, 4. Baskı, Dost, Ankara, s. 59; Altınordu, Fazıl (2012) AİHS’ne Göre Ayrımcılık Yasağı ve Türk Hukukunda Gelişimi, 1. Baskı, Ankara, Adalet, s. 5-8; Serozan, Rona (2013) Marx/Engels Devlet ve Hukuk Üzerine, 3. Baskı, İstanbul, Çağdaş Hukukçular Derneği, s. 61,89.

184 Akın, F. İlhan (2016) Devlet Doktrinleri, 3. Baskı, İstanbul, Beta, s. 163.

185 Doğru, s. 81; Öztürk, s. 39.

186 Şenel, Alaeddin (1969) "Eşitlik Kavramı ve Tarihsel Gelişimi” Yavuz Abadan’a Armağan, Ankara, Ankara Üniversitesi Sosyal Bilgiler Fakültesi, s. 241-268; Altınordu, s. 9. 
olarak da tanımlanmaktadır ${ }^{187}$. Bu bağlamda eşit durumda olanlara eşit davranmamak yahut eşit durumda olmayanlara eşit davranmak eşitlik ilkesinin ihlalidir ${ }^{188}$.

Eşitliğin hukuki niteliği öğretide tartışılmış, sonuçta ilkeden yararlananlar için eşit işlem görme ayrım gözetilmemesini isteme bir hak olarak nitelendirilmiştir. Bu hakkın muhatapları devlet organları ve idare makamları açısından ise devlet yönetimine egemen bir ilke, bir buyruk olarak vasıflandırılmıştır ${ }^{189}$.

Hukuki bir bağlayıcılığı bulunmasa da tarihi, felsefi, ahlaki ve manevi öneme sahip ${ }^{190}$ olan İnsan Hakları Evrensel Bildirisi'nin 1948'de yayınlanması ile eşitlik ilkesi evrensel nitelik kazanmakta önemli bir yol kat etmiştir. Bu Bildiri ile bütün insanların eşit olması, özgürlük ve kardeşliğin temelinde yer alan evrensel bir değer ve temel bir ilke olarak nitelendirilmiştir. Kaldı ki bu Bildiri'nin ardından devletlere bireylerine eşitlik sağlama yükümlülüğü yükleyen, bu konuda ayrıntılı hükümlere yer veren bu ilkeden yola çıkarak hiçbir birey arasında ayrımcılık yapılamayacağı ilkesini de içeren Kişisel ve Siyasal Haklara İlişkin Uluslararası Sözleşme ve Avrupa İnsan Hakları Sözleşmesi gibi sözleşmeler imzalanmıştır ${ }^{191}$.

1961 Anayasası'nda temel hak ve özgürlüklerin arasında düzenlenme imkanı bulan eşitlik hakkı, 1982 Anayasası'nda da 1961 Anayasası'ndaki hükmü tekrarlayarak Genel Esaslar kısmında yer alarak, 10. maddede düzenlenmiştir. Eşitlik ilkesi incelendiğinde hiçbir bireye imtiyaz tanınamayacağı belirtilmekte, kadın ve erkeğin eşit olduğu belirtilmektedir. Bu düzenlemeden de ayrımcılık yasağı sonucu çıkmaktadır ${ }^{192}$.

187 Araslı, s. 165.

188 Karan, Ulaş, Eşitlik İlkesi ve Ayrımcılık Yasağı: Hukuksal Çerçeve, ss. 1-13, $<\mathrm{http}: / /$ secbir.org

/images/haber/2011/01/12-ulas-karan.pdf>, s.e.t.17.02.2020, s. 5; Tanör/Yüzbaşığlu, s. 124.

189 Özbudun, s. 156.

190 Akın, F. İlhan (1980) Kamu Hukuku: Devlet Doktrinleri-Temel Hak ve Özgürlükler, 2. Baskı, İstanbul, İstanbul Üniversitesi Hukuk Fakültesi, s. 370-371; Kapani, s. 62-63.

191 Öden, Merih (2003) Türk Anayasa Hukukunda Eşitlik İlkesi, Ankara, Yetkin, s. 85.

192 Tanör/Yüzbaşığlu, s. 122-123. 
Sağlık hakkı da eşit durumdakilere eşit olarak tanınan, farklı durumda olan kişilere farklı şekilde sunulabilen, bireylere eşit bir şekilde sağlık hizmetlerinden yararlanma imkanı sağlaması gereken, sağlık hakkından yararlanmaya engel teşkil eden bir durum olması halinde ise söz konusu engelin kaldırılmasına temel teşkil eden bir haktır. Bu nedenle eşitlik ilkesi sağlık hakkın tüm bireylere eşit bir şekilde tanınması, sağlık hizmetinin herkese eşit olarak uygulanması açısından oldukça önem taşımaktadır. Nitekim AYM'nin de kamu hizmetlerinin sunumunda nispi eşitlik ilkesinin uygulanmasına ilişkin kararlar1 ${ }^{193}$ bulunmaktadır.

\section{Ayrımcılık Yasağı}

Objektif ve makul bir sebep olmaksızın eşitlik ilkesine uymadan hareket ederek ayrımcılık yapmak, ayrımcılık yasağının ihlali şeklinde nitelendirilmektedir ${ }^{194}$. Objektif ve makul sebebin varlığı, ilk olarak varılmak istenen amaç ile kullanılan aracın orantılılığına ${ }^{195}$, ikinci olarak tasarrufun

193 AYM’nin eşitliği tanımladığı ve kamu hizmetinde eşitlik ilkesini temel ilke olarak belirttiği bir kararına bkz.: "...Eşitlik ilkesi, ortada haklı bir neden bulunmadıkça hiçbir kişiye, aileye, zümreye ya da sınıfa ayrıcalık tanınmasına mutlak engeldir. Kamu hizmetinde eşit davranış eşit yararlanma temel niteliktir...” AYM, E.1987/3, K.1987/13, K.T.22.05.1987,19578 Sayılı R.G., Y.T.18.09.1987;

Kamu hizmetinin sunulmasında eşitlik ilkesine ilişkin diğer bir AYM kararına bkz:: “...Eşitlik, herkesin her yönden aynı yasa hükmüne bağlı olacağı anlamında ele alınamaz. Kimi kişilerin başka kurallara bağlı tutulmalarında haklı neden varsa, bu durumda yasa önünde eşitlik ilkesine aykırılıktan söz edilemez...” AYM, E.1990/15, K.1991/5, K.T.28.02.1991, 21184 Sayılı R.G., Y.T.27.03.1992; AYM, E.1986/16, K.1986/25, K.T.21.10.1986, 19358 Sayılı R.G., Y.T.31.01.1987;

Aynı yönde diğer bir AYM kararına bkz.: “...Hukuksal durumları ve nitelikleri farklı olan kuruluşlar ayrı kurallara bağlı tutulursa Anayasa'nın öngördü̈̆̈̈ eşitlik bozulmaz...” AYM, E.1991/5, K.1992/9, K.T.18.02.1992, 21221 Sayılı R.G., Y.T.07.05.1992.

İnceoğlu, Sibel, (2001) “Türk Anayasa Mahkemesi ve Avrupa İnsan Hakları Mahkemesi Kararlarında Eşitlik İlkesi ve Ayrımcılık Yasağın Çerçevesinde Af, Şartla Salıverme, Dava ve Cezaların Ertelenmesi” Anayasa Yargısı, C. 18, ss. 41-70, s. 59; Tezcan/Erdem/Sancakdar ve Diğerleri, s. 549; Demren Dönmez, s. 24; Doğru, s. 81; Özbudun, s. 158.

Karan, Ulaş (2007) “Türk Hukukunda Ayrımcilık Yasağ1 ve Türk Ceza Kanunu'nun 122. Maddesinin Uygulanabilirliği” Türkiye Barolar Birliği, Sa. 73, ss. 146-173, s. 154. 
amacı ile sonucu arasında var olan ilişkiye ve son olarak da toplumdaki bireylerin yaşamını belirleyen hukuki ve fiili unsurlara bakılarak tespit edilir ${ }^{196}$.

Ayrımcılık, doğrudan ve dolaylı ayrımcılık olmak üzere ikiye ayrılır. Doğrudan ayrımcılık, kişilere cinsiyet, ırk gibi temellere dayanarak diğer kişilerden daha az olumlu davranmaktır ${ }^{197}$. Dolaylı ayrımcılık ise doğrudan ayrımcllık ile izlenen amaca farklı bir yöntemle, dolaylı olarak ulaşılması anlamına gelmektedir ${ }^{198}$. Bu ayrımcllık türünde her ne kadar söz konusu grup doğrudan o hareketten etkilenmiyor gibi görünse de avantajsız duruma düşmektedir ${ }^{199}$.

AİHS’in 14. maddesi, ayrımcılığın doğrudan düzenlendiği temel maddedir. Bu madde din, dil, urk, cinsiyet, ulusal yahut sosyal köken, siyasi düşünce ayrımı gözetilmeksizin tüm bireylerin Sözleşme'deki haklardan yararlanmasını düzenler ${ }^{200}$. Ayrım yapılmasının açıkça yasaklanmış olduğu 14 . madde, yasalar önünde eşitlik ilkesinin bir yansımasıdır. Bu madde ile aynı durumda bulunan kişilerin haksız olarak farklı muameleye tabi olmaları da yasaklanmaktadır; ancak bu yasağın, diğer uluslararası belgeler ${ }^{201}$ ile karşılaştırıldığında yalnızca AİHS’in içerisindeki haklara ilişkin bir yasak olması ve bağımsız bir yasaklama olmaması nedeniyle, bu maddenin sınırlı kaldığı görülmektedir ${ }^{202}$.

2000'de AİHS'e ek 12. Protokol eklenmiş ve Sözleşme'deki haklardan bağımsız olarak genel bir ayrımcılık yasağı sözleşmeye bu ekleme ile birlikte dahil olmuş, tüm insanların hukuk önünde eşit olmaları ve hukuk tarafından

196 Doğru, s. 82.

197 Duvefelt, Sabine/Sjölander, Carolina (2009) “Multiple Discrimination”, Örebro University Department of Behavioural, Social and Legal Sciences, Legal Science Programme with International Approach, 240 ECTS Bachelor Thesis of 15 ECTS, Örebro, <http://oru.divaportal.org/smash/record.jsf?pid=diva2\%3A135

$637 \&$ dswid $=0.8100786764248513>$, s.e.t.17.02.2020, s. 4; Tezcan/Erdem/Sancakdar ve Diğerleri, s. 553.

198 Demren Dönmez, s. 12-13.

199 Duvefelt/Sjölander, s. 4; Tezcan/Erdem/Sancakdar ve Diğerleri, s. 553.

200 Gözübüyük/Gölcüklü, s. 19.

201 Gemalmaz, s. 289-445.

202 Doğru, s. 81; Altınordu, s. 23. 
eşit derecede korunma hakkına sahip olmaları ilkesi temel alınarak, devletlerin kişiler arasında ayrımcılık yapılmaması için gereken tüm tedbirleri objektif ve makul bir gerekçeye dayanarak alması hususunda düzenleme getirilmiştir ${ }^{203} . \mathrm{Bu}$ düzenlemenin yapılmasının nedeni, eşitlik ilkesi ile bu ilkenin yansıması olan ayrımcılık yasağının uluslararası insan hakları hukukunun temel ilkesi olması ve özel bir dikkat gerektirmesidir ${ }^{204}$.

Türk anayasalarındaki eşitlik ilkesi ve ayrımcllık yasağına ilişkin hükümlerin başında, 1924 Anayasası'nda 88. ve 69. maddeler ile eşitlik ilkesinin düzenlenmesi gelmektedir. 88. Maddede, Türk olmanın din ve irka göre değişmeyeceği, 69. maddede ise yasalar önünde eşitliğin sağlandığı; ancak sosyal ve ekonomik alanda eşitliğin kişinin gücü ile belirleneceği belirtilmiştir. 1961 Anayasası'nın 12. Maddesinde Evrensel Bildiriler tarafindan kabul edilen din, dil, ırk, mezhep, felsefi yahut siyasal düşünce veya cinsiyet ayrımı olmaksızın tüm bireylerin yasalar önünde eşitliği düzenlenmiştir ${ }^{205} .1982$ Anayasası'nın 10. maddesinde, 1961 Anayasası'ndaki düzenlemenin tekrar edilmesinin yanı sıra, kadınlar ve erkeklerin eşit olduğu açık bir şekilde belirtilmiş, ayrıca devlete de bu durumu sağlamada yükümlülükler yüklemekle birlikte işlem ve kamu hizmetlerinde kanun önünde eşitlik ilkesi doğrultusunda hareket etmeleri yönünde düzenleme getirmiştir. 1982 Anayasası'nda gerek 10. maddede kadın ve erkeğin açık olarak belirtilmesi gerekse 41. maddede ailede eşlerin eşit olması ve eğitim hakkının düzenlendiği 42. maddede kız ve erkek için zorunlu olduğunun açık olarak belirtilmesi ve 50. maddede çalışma hakkı ile ilgili düzenlemelerde kimsenin cinsiyetine uygun olmayan işlerde çalıştırılamayacağının belirtilmesi nedeniyle cinsiyete dayalı ayrımcılığın yasak olduğu kanunlar ile hüküm altına alınmıştır. Din ve mezhep ayrımcılığı da 10. maddenin yanı sıra, aynı zamanda 24. maddede hüküm altına alınan din ve vicdan özgürlüğü ile de yasaklanmış ve hatta din ve mezhep farklılığı ayrımcılığın ötesinde bir özgürlüğe konu olmuştur ${ }^{206}$. TCK’nın da 122.

\footnotetext{
203 Altınordu, s. 26.

204 İnceoğlu, s. 58; Doğru, s. 81.

205 Akın (1980), s. 315.

206 Altınordu, s. 24-84.
} 
maddesinde ayrımcılık yasağı hüküm altına alınarak ihlali halinde suçun failine uygulanacak cezalar düzenlenmiştir.

Devlet, açıklanan hükümlerin ışığında, kişilere sahip olduğu özelliklere göre farklı davranmamalı, fırsat eşitliğini sağlamalı ${ }^{207}$, yani bireylerin doğuştan sosyal, politik ve ekonomik alanlardan sahip olduğu özellikler yüzünden ayrımcılıktan doğan eşitsizliklerini, dışlanmalarını azaltmalı ve uzun vadede söz konusu eşitsizliklerin önüne geçilmesi amacıyla pozitif ayrımcılık yapmalıdır ${ }^{208}$. Nitekim devlet, diğer gerçek ve tüzel kişiler tarafından ayrımcılık yapılmasını önleyici tedbirler almalı ve ayrımcılık yasağını ihlal edenleri de etkili bir soruşturma ve kovuşturmadan geçirmelidir. Bu bağlamda devletin eşitlik hakkı ışığında ayrımcılık yasağına ilişkin hem negatif hem de pozitif yükümlülükleri haiz olduğunu belirtmek gerekir ${ }^{209}$.

Bireyler, sağlık hakkını kullanarak sağlık hizmetlerinden yararlanırken hekim yahut diğer sağlık memurları tarafından ayrımcılığa maruz kalmamalıdır. Nitekim hekim veya diğer sağlı memurları, yalnızca kanun ile tanınan bazı önceliklerden olan engellilik yahut tıbbi durumun gerektirdiği öncelikler gibi durumların varlığı halinde o kişilere öncelikli davranabilmektedir. Aksi takdirde, bu durumlar yok ve hekim kişilere öncelikli davranıyor ise eşitlik ve hakkaniyet ölçüleri dışına çıkılmış, AİHS.m.14'te belirtilen ayrımcılık yasağı da AY.m.10 da ihlal edilmiş demektir. Belirtilmelidir ki sağlık alanında eşitlik ilkesi, bütün insanların eşit bir şekilde sağlık durumları olması anlamına gelmemekte, bütün insanların sağlık hizmetine erişimde eşit olanakları haiz olması anlamına gelmektedir ${ }^{210}$.

207 Özbudun, s. 141.

208 Tezcan/Erdem/Sancakdar ve Diğerleri, s. 554.

209 Avrupa Konseyi, Avrupa Birliği Temel Haklar Ajansı (2010) Avrupa Ayrımcılık Yasağı Hukuku El Kitabı, s. 16, 35-38; Gül, İdil Işıl/Karan, Ulaş (2011) Ayrımcılık Yasağı Eğitim Rehberi, 1. Bask1, İstanbul, İstanbul Bilgi Üniversitesi, s. 53.

210 Kızllkaya Doğru, Ezgi (2016) Tıbbi Müdahaleler Karşısında İnsan Hakları, Açlık Grevi ve AIDS/HIV, 1. Bask1, Ankara, Adalet, s. 22. 


\section{D. Özel Hayatın Gizliliği İlkesi}

Öğretide kavram ve temel haklardan biri olarak ele alınan ve tanımlanan özel hayatın gizliliği ilkesinin ilk tanımı, bireyin başkalarının bilgisinden uzak kalmasını, sadece kendisinde saklı kalmasını istediği yaşam görünümlerinin gizli kalmasıdı2²11. Başka bir tanıma göre özel hayatın gizliliği, herkes tarafından bilinmeyen, ancak araştırma sonucu elde edilebilen kişiye ait özel bilgilerin kişinin bilgisi dâhilinde kalması, başkaları tarafından öğrenilmemesidir ${ }^{212}$. Diğer bir tanıma göre, kişiliğin gelişmesi için kişinin kendine ait gizli bir alanı vardır ki o kişinin izni olmadan kimse bu alanı öğrenememelidir, buna özel hayatın gizliliği denir ${ }^{213}$. Bir görüşe göre özel hayatın gizliliği, bireylerin kendi hayatlarında başka kişiler tarafından bilinmemesini istedikleri yönlerinin bilinmemesi, bu yönlerine başkalarının nüfuz etmemesidir ${ }^{214}$. Diğer bir görüş ise özel hayatın gizliliğini kişinin ancak kendisinin özel hayatının düzeni ile bu hayata kimlerin, ne zaman, hangi ölçüde müdahale edebileceğine karar vermesi şeklinde tanımlamaktadır ${ }^{215}$.

Özel hayatın gizliliği, uluslararası hukukta birçok belgede düzenlenmiş olup ${ }^{216}$, özellikle AİHS.m.8'de özel hayata hangi araçlarla (kanun/hukuk), hangi amaçlarla (sınırlama nedenleri) ve hangi ölçüde (demokratik toplumda gereklilik) müdahale edilebileceği düzenlenmiştir ${ }^{217}$.Insanın sırf insan olması nedeniyle sahip olduğu ${ }^{218}$ özel hayata saygı hakkı olarak da adlandırılan özel hayatın gizliliği hakkı, devlete bireylerin özel hayatlarının gizli kalmasına saygı göstermesi, özel hayatlarına müdahale etmemesi şeklinde ihlalde bulunmama

211

Özsunay, Ergun (1982) Gerçek Kişilerin Hukuki Durumu, 5. Baskı, İstanbul, Der, s. 127-137. Özek, Çetin (1978) Türk Basın Hukuku, 1. Baskı, İstanbul, İstanbul Üniversitesi, s. 259.

Karahasan, Mustafa Reşit, (1976) Tazminat Davaları, Yenilenmiş ve Genişletilmiş Baskı, İstanbul, İstanbul Matbaası, s. 783.

Ataay, Aytekin (1978) Şahıslar Hukuku: Birinci Yarım Girişi-Hakiki Şahıslar, 3. Baskı, İstanbul, İstanbul Üniversitesi, s. 131.

15 Şen, Ersan (1996) Devlet ve Kitle İletişim Araçları Karşısında Özel Hayatın Gizliliği ve Korunması, İstanbul, Kazanc1, s. 5-6.

16 Zafer, Hamide, (2010) Özel Hayatın Gizli Alanının Ceza Hukukuyla Korunması, 1. Baskı, İstanbul, Beta, s. 28-40; Şen, s. 59-84.

Doğru, s. 44; Güntürk, s. 102 vd..

Güntürk, s. 59. 
yükümlülüğünü yükleyerek negatif statü hakkı özelliğini taşısa da öte yandan yalnızca bu yükümlülüğü yüklememekte, aynı zamanda bireylerin özel hayatlarının gizli kalmasını sağlaması, ihlal etmeye çalışanları engelleyici tedbirler alması şeklinde hakkın etkin bir şekilde korunmasını ve bireylerce uygulanmasını sağlayacak düzenlemeler yapma yükümlülügünü de yüklemesi nedeniyle pozitif statü hakkı özelliğini de göstermektedir ${ }^{219}$.

Özel hayatın gizliliği ilkesi, gerek kamu gerekse özel hukuk alanında yer alan bir ilkedir, haktır. Kamu hukuku kapsamında Türk anayasalarında bu hak, 1924 Anayasası'nda yer almamış, 1961 Anayasası'nda 15. maddede ve 1982 Anayasası'nda 20. maddede "Kişinin Hak ve Ödevleri” başlığı altında yer alan temel hakların arasında düzenlenmiştir. 20. Maddenin 1. fikrasında, “...Herkes, özel hayatına ve aile hayatına sayg gösterilmesini isteme hakkına sahiptir. Özel hayatın ve aile hayatının gizliliğine dokunulamaz..." şeklinde düzenlenen özel hayatın gizliliği ilkesi, 2. ve 3. fikralarda kişisel verilerin korunmasına dair hükümlerle daha kapsamlı bir şekilde düzenlenme imkanı bulmuştur. Bu bağlamda özel hayatın gizliliği hakkı, her bireyin sahip olduğu, devredilemez, dokunulamaz, vazgeçilemez bir temel haktır ${ }^{220}$. TCK'nın 134. maddesi, doğrudan özel hayatın gizliliğini koruma altına almışken, 136. ve 137. maddeleri de özel hayata ilişkin kişisel verilerin korunmasına dair hükümler getirmiştir.

Özel hukukta özel hayatın gizliliği ve korunması hakkı temel kişilik haklarından sayılmaktadır. Bu hak kişinin bedeni ve manevi bütünlüğünü de içermektedir ${ }^{221}$. Kişilik hakkı olarak özel hayatın gizliliği hakkı, tüm bireylerin sahip olduğu, herkese karşı ileri sürülebilen, vazgeçilmesi ve başka bir bireye devri mümkün olmayan mutlak bir hak özelliğini göstermektedir ${ }^{222}$. Özel hukukta da kamu hukukunda da kişinin özel alanı, bireyin yalnızca sınırlı

219 Salihpaşaoğlu, Yaşar, (2013) “Özel Hayatın Kapsamı: Avrupa İnsan Hakları Mahkemesi İçtihatları Işığında Bir Değerlendirme” Gazi Üniversitesi Hukuk Fakültesi, C. XVII, Sa. 3, ss. 227-266, s. 251-252; Kızılarslan, s. 60; Doğru, s. 45; Koca/Üzülmez, s. 465.

220 Şen, s. 9; Korkusuz, M. Refik (1998) Uluslararası Belgelerde ve Türk Anayasası'nda Temel Hak ve Özgürlükler, 1. Bask1, İstanbul, Örnek, s. 249-252.

221 Kizllarslan, s. 61; Özsunay, s. 127.

222 Dural, Mustafa/Öğüz, Tufan, (2010) Türk Özel Hukuku Cilt II Kişiler Hukuku, 10. Baskı, İstanbul, Filiz, s. 97. 
kişiler tarafından bilinmesini istediği, özellikle kamudan gizlediği, yalnızca ailesi, yakın dostları veya güvendiği kişilerle paylaştığı alanıdır ${ }^{223}$. Kişinin özel hayat alanında, gerçek adı, adresi, yaşı, ailevi durumu, boş zamanlarındaki aktiviteleri, malvarlığı ile günlük alışkanlıkları yer almaktadır ${ }^{224}$. Gizlilik alanı ise üçüncü kişilerden gizlemiş olduğu ve yalnızca kendi istediği kişilerce bilinen olayları içeren alandır ${ }^{225}$. Bu bağlamda kişinin özel ve gizlilik alanına yapılacak her türlü müdahale kişilik hakkı ihlali olarak kabul edilerek TMK.m.24 kapsamında korunmaktadır ${ }^{226}$.

Sağlık hukukuna ilişkin mevzuatlarda da sağlık hakkını kullanarak sağlık hizmetinden yararlanan hastaların özel hayatının gizliliğine dair hükümler getirilmiştir. Türk Tabipleri Birliği Disiplin Yönetmeliği’nin 3. maddesinde hasta haklarına saygılı olunacağı düzenlenirken özel hayatın gizliliğinin de ihlali önlenmeye çalışılmaktadır. Aynı yönetmeliğin 5. maddesinde de hastaların özel hayatlarına dair sırlarının açığa çıkarılması, geçici olarak meslekten alıkoyma cezasının verilmesini gerektirmektedir. Hekimlik Mesleği Etik Kuralları’nın 9. maddesinde hekimlerin sır tutma yükümlülüğü düzenlenerek hastaların özel hayatlarının gizli tutulmasının sağlanması amaçlanmıştır. Hasta Hakları Yönetmeliği'nin Mahremiyete Saygı Gösterilmesi başlığını taşıyan 20., 21., 22. ve 23. maddelerinde ayrıntılarıyla hastaların özel hayatlarına saygı gösterilmesi gerektiği düzenlenmiş, tıbbi müdahalede bulunan hekimlerin hastaların özel hayatının gizliliğini ihlal etmeden hareket etmesi gerektiği de vurgulanmıştır. Yargı kararlarında da sağlık hakkını kullanarak sağlık hizmetinden yararlanan hastaların özel hayatının gizliliğinin ihlali konu olmuştur. Danıştay'ın HIV testinin sonucunun hastanın kişisel verisi olduğu ve gizli tutulması gerektiği buna aykırı hareket eden laboratuvar teknisyeninin idarenin ağır hizmet kusurunu oluşturduğuna ilişkin 2007 tarihli

223 Danışman, Ahmet (1991) Ceza Hukuku Açısından Özel Hayatın Korunması, 1. Baskı, Konya, Selçuk Üniversitesi, s. 8-9; Zafer, s. 13; Dural/Öğüz, s. 127-128; Güntürk, s. 50-51; Özek, s. 260.

224 Korkusuz, s. 247.

225 Dural/Öğüz, s. 128; Güntürk, s. 51-54; Özsunay, s. 127-128; Özek, s. 260.

226 Dural/Öğüz, s. 128-129. 
bir karar1 ${ }^{227}$ bulunmaktadır. Hasta, kendi hastalığına ilişkin yahut hekime vermiş olduğu herhangi bir bilginin hekimde bir sır önemi taşımasını ve hekimin onu sadakatle sır olarak saklamasını ister. Keza hekimin de en önemli yükümlülükleri tıbbi özen gösterme ile sır saklama yükümlülüğüdür ${ }^{228}$. Bu yükümlülük, hastaya dair hiçbir bilginin açıklanmaması anlamına gelmemekte, hastanın bilgilerinin açıklanmasına dair hukuki bir yükümlülük bulunması yahut açıklanmasında üstün kamu yararının bulunması halinde hastanın rızası ile bilgilerin açıklanması anlamına gelmektedir ${ }^{229}$; ancak hekimin söz konusu bilgileri sır olarak saklaması yalnızca hastalığına ilişkin bilgiler için değil, özel hayatına dair tüm bilgiler için geçerlidir ${ }^{230}$. Belirtilmelidir ki kişilerin kendi tedavilerine ilişkin tıbbi kayıtlara ulaşmalarına izin verilmemesi de özel hayatın gizliliğinin ihlalidir ${ }^{231}$.Keza sağlık hakkıyla ilgili bir dava olan Juhnke v. Turkey davasında $^{232}$ AİHM, herhangi bir sebep olmaksızın ilgilinin rızası dışında yapılan jinekolojik muayeneyi kişinin özel hayatının gizliliğinin ihlali olarak değerlendirmiştir.

\section{SONUÇ}

Çalışmamızda uluslararası ve ulusal mevzuatın yanı sıra, ilkeler ile sağlık hakkının nasıl koruma altına alındığı ve temel kamu hizmetlerinden sağlık hizmetinin dayanağının neler olduğu açıklanmıştır.

Uluslararası mevzuatta ilk olarak dikkati çeken yaşama hakkının temelinde yer alan sağlık hakkının, kimi düzenlemede başlı başına bir hak

\footnotetext{
227 Danıştay 10.D., $\quad$ E.2005/8407, $\quad$ K.2007/6526, $\quad$ K.T.28.12.2007, $<$ http://www.kazanci.com/kho2/ibb/files/dsp. php?fn=10d-2005-8407.htm\&kw=`E.2005/8407`\#fm>, s.e.t.17.02.2020.

228 Öztürk, s. 57.

229 Koç, Seda (2007) “İnsan Hakları Sözleşmesinin Tıbbi Karar Alma Sürecine Etkileri (1998)” Özel Yaşam, Medya ve Ceza Hukuku, 1. Baskı, Ankara, Seçkin, s. 397-398.

230 Kizllkaya Doğru, s. 19-21.

231 Koç, s. 396.

232 Case of Juhnke v. Turkey, Application No. 52515/99, Judgment 13/08/2008, s. 11-12 $<$ http://hudoc.echr.coe. int/eng\#\{"languageisocode":["TUR"],"appno":["52515/99"],"documentcollectionid2":["CHA MBER"]\}>, s.e.t.09.10.2018.
} 
olarak hüküm altına alınmışken kimi düzenlemede yaşama hakkı ile bir bütün olarak ele alındığı, yaşama hakkı açıklanırken içerisinde bir kavram olarak geçtiği kimi düzenlemede ise yaşama hakkı tanımlanırken sağlık hakkının da açık olarak tanımlanmış olduğu kimilerinde ise sağlık hizmetinin düzenlendiğidir. $\mathrm{Bu}$ durum yaşama hakkı ile sağlık hakkının ne kadar yakın haklar olduğunu ve hatta iç içe geçmiş haklar olarak da ele alınabileceğini göstermektedir. Fikrimizce sağlık hakkının korunması için uluslararası mevzuatta yapılan tanımlamaların ve korunması amaciyla getirilen düzenlemelerin mutlaka "sağlık hakkı" başlığı altında yer alması gerekmemektedir. Önemli olan sağlık hakkının bir temel hak olarak dikkate alınıp, söz konusu yasal düzenlemelerde koruma mekanizmaları ile korunup, geliştirilmeye yönelik çalışmalara temel alınmış olmasıdır. Uluslararası mevzuat kapsamında sağlık hakkının ve sağlık hizmetinin tanımlanması, gelişmesi amacıyla düzenlemeler yapılmasının yanı sıra, aynı amaçla çeşitli politikalar da izlenmiştir. Bu politikalar ile de sağlık hakkı temel insan haklarından biri olarak benimsenmiş ve gerek sağlık hakkının gerek sağlık hizmetinin daha çok geliştirilmesine yönelik çalışmalar yapılmıştır. Çeşitli politikalarla birlikte hasta hakları, hekim hakları, hastaların kişisel verilerinin korunması, aydınlatılmış onam gibi sağlık hakkından doğan haklar da uluslararası mevzuatta düzenlenerek sağlık alanında kurallar bütünü ile hareket edilmesi ve sağlık hizmetinin sunulması esnasında sağlık hakkının ihlalinin önüne geçilmesi amaçlanmıştır. Ulusal mevzuatta yer alan anayasalardan biri olan 1921 Anayasası, savaş sonrası dönemde çıkarılan ve yalnızca zaruri temel haklardan bir kısmını düzenleyen bir anayasa olması nedeniyle ne yaşama hakkı ne de sağlık hakkına dair bir hüküm içermektedir. Bu yönüyle de çalışmamızın konusunu oluşturan, en temel hak olan sağlık hakkının ${ }^{233}$ yanı sıra, yaşama hakkını dahi içermeyen anayasa, fikrimizce eksik bir anayasa olarak nitelendirilebilmektedir. 1921 Anayasası'nın aksine 1924, 1961 ve 1982 yıllarında düzenlenen Türkiye Cumhuriyeti anayasalarında ise kiminde yalnızca yaşama hakkı kiminde hem yaşama hem de sağlık hakkı koruma altına alınmış, sağlık hizmeti düzenlenmiştir. Anayasalardaki düzenlemeler

233 Temiz (2013), s. 70. 
incelendiğinde ise yaşama hakkı ile sağlık hakkının bir bütün olarak ele alındığı, ayrı bir hak olarak düşünülmediği sonucuna varılabilmektedir.

Ulusal mevzuatta anayasalardan sonra yllardan beri uygulanan kanunlar, nizamnameler, yönetmelikler ile son zamanlarda yürürlüğe giren KHKlar, CBKlar sağlık hakkının korunması ve sağlık hizmetinin dayanağının oluşturulması ve geliştirilmesi amacıyla düzenlemeler içermektedir. Kimi düzenleme temel kuralları belirlemiş, hakkın korunması amacıyla etkili hükümleri oldukça kapsamlı düzenlemiştir ki yıllar geçse ve hatta sağlık kurumları, personellerinin yapısı değişse bile yasal düzenlemenin ismi dahi aynı kalmış, tamamen mülga olmamış, yalnızca içerisinde küçük madde değişikliklerine uğrayarak günümüze kadar uygulanmaya devam etmiştir. Süreç içerisindeki yeniliklere karşın kanunun halen geçerli olması, yasa koyucunun dönemin şartlarını, teknolojinin ve yeni gelişmeleri gözeterek kanun yaptı̆̆ının göstergesidir. Kimi düzenleme ise güncel gelişmeler doğrultusunda sağlık hizmeti idari teşkilatını yeniden, günümüze uygun bir şekilde düzenleyerek sağlık sistemindeki ihtiyaçları gidermeye yönelik hükümler getirmiş ve idare hukuku açısından önemli değişikliklere neden olmuştur.

Uluslararası ve ulusal mevzuat ile düzenlenip korunan sağlık hakkı ve hukuki temelleri kurulan sağlık hizmeti, ilkeler ile de tanınmakta ve uygulanması sağlanmaktadır. Bu ilkelerden hukuk devleti ilkesi bireylerin haklarını kullanabilmeleri için temel ilke olarak karşımıza çıkmakta, dolayısıyla sağlık hakkının bireylere tanınması ve sağlık hizmetinin gereği gibi uygulanabilmesi için de önem taşıyan ilke olarak ele alınmaktadır. Sosyal devlet ilkesi ise özellikle özel sağlık kuruluşlarının sayısının gün geçtikçe artması ve acil müdahale gereken zamanlarda en yakın sağlık kuruluşu olduğu için hastaların bu kuruluşlara götürülmesi durumunda para talep edilip edilemeyeceği, talep edilmesinin kabul edilmesi halinde ekonomik olarak gücü yetmeyen bireylerden bu paranın alınamaması ihtimalinde sağlık hizmetinden yararlanıp yararlanamayacakları konularına ilişkin tartışmaların temelinde yer alması yönüyle öne çıkan bir ilke olarak dikkati çekmektedir. İnsan onurunun korunması ilkesi ile işkence yasağı genellikle birlikte incelenmekte ve bu ilkeler bireylerin sağlık hakkını kullanarak sağlık hizmetinden yararlanırlarken insan 
onuruna aykırı hareket edilmesini ve işkence olarak nitelendirilebilecek davranışlardan uzak durulmasını sağlamaktadır. Eşitlik ilkesi ve ayrımcılık yasağı, sağlık hakkını kullanarak sağlık hizmetinden yararlanan her bireye eşit olarak davranılmasını, bireylerin herhangi bir özelliğinden dolayı ayrımcılık yapılmasının önlenmesini sağlamakta ve bu sayede bireylerin sağlık hakkını korumaktadır. Son olarak özel hayatın gizliliği ilkesi ise sağlık hakkı çerçevesinde sağlık hizmetine başvuran bireylerin kişisel bilgilerinin, özel hayatlarının üçüncü kişilere açıklanmasını önleyerek sağlık hakkını kullanmalarına ve sağlık hizmetinden yararlanmalarına imkan tanıyan ilke olarak karşımıza çıkmakta ve büyük önem taşımaktadır. 


\section{KAYNAKÇA}

Altınordu, Fazıl (2012) AİHS’ne Göre Ayrımcllık Yasağı ve Türk Hukukunda Gelişimi, 1.Baskı, Ankara, Adalet.

Akad, Mehmet/Vural Dinçkol, Bihterin/Bulut, Nihat (2016) Genel Kamu Hukuku, 12.Baskı, İstanbul, Der.

Akgül, Aydın (2014) "İşkence Nedeniyle Açılan Tam Yargı Davalarında Danıştay Ölçütleri”, Türkiye Barolar Birliği, Sa.112, ss.189-236.

Akın, F. İlhan (2016) Devlet Doktrinleri, 3.Baskı, İstanbul, Beta.

Akın, F. İlhan (1980) Kamu Hukuku: Devlet Doktrinleri-Temel Hak ve Özgürlükler, 2.Baskı, İstanbul, İstanbul Üniversitesi Hukuk Fakültesi.

Aksakoğlu, Gazanfer (2003) “Dünya Sağlık Örgütü ve Sağlık Politikalarında Değişim”, Sol, Sa.199, C.41-5, ss.1-7.

Aktan, Coşkun Can/Işık, A. Kadir, Sağlığın Korunması ve Geliştirilmesine Yönelik Evrensel Sağlik Bildirgelerine Toplu Bir Bakış,<http://www.canaktan.org/ekonomi/saglik-degisim-caginda/pdfaktan/sagligin-korunmasi.pdf>, s.e.t.02.10.2018, ss.1-34.

Aldanmaz, Orhan (2010) “İnsan Onuru Işığında Kişisel Özerklik ve Yerellik İlkesi”, Erzincan Üniversitesi Hukuk Fakültesi, C.XIV, Sa.1-2, ss.79-109.

Anayurt, Ömer (2008) “Avrupa İnsan Hakları Mahkemesi İçtihatlarında İşkence Kavramı”, Gazi Üniversitesi Hukuk Fakültesi, C.II, Sa.1-2, ss.421-459.

Annas, George J. (2005) Human Rights and Helath: The Universal Declaration of Human Rights at 50, Perspectives on Health and Human Rights, New York-London, Routledge.

Araslı, Utkan (2015) Anayasal Temel İlke ve Kavramlar, 1.Baskı, Ankara, Türkiye Barolar Birliği.

Arslan, Kahan Onur (2015) "İnsan Onuru Kavramı ve Koruma Tedbirleri Bağlamında Temel Bir İlke Olarak İnsan Onurunun Korunması”, Türkiye Barolar Birliği, Sa.120, ss.155-172. 
Artuk, Mehmet Emin/Gökcen, Ahmet/Yenidünya, A. Caner (2006) Ceza Hukuku Özel Hükümler, 7.Baskı, Ankara, Turhan.

Ataay, Aytekin (1978) Şahıslar Hukuku: Birinci Yarım Girişi-Hakiki Şahıslar, 3.Baskı, İstanbul, İstanbul Üniversitesi.

Avrupa Konseyi, Avrupa Birliği Temel Haklar Ajansı (2010) Avrupa Ayrımcılık Yasağı Hukuku El Kitabı.

Balkır, Zehra Gönül (2009) Türk Anayasa Yargısında Sosyal Hakların Korunması, 1.Baskı, Kocaeli, Kocaeli Üniversitesi Yayınları Yayın No. 335.

Başbakanlık, Ulusal Tütün Kontrol Programı Genelgesi, (2006) No. 2006/29, 26312 Sayılı R.G., Y.T.07.10.2006.

Barroso, Luis Roberto (2012) "Here, There and Everywhere: Human Dignity in Contemporary Law and in the Transnational Discourse", Boston College International and Comparative Law Review, Volume 35, Issue 2, Article 2, <http://lawdigitalcommons.bc. $\mathrm{edu} / \mathrm{iclr} / \mathrm{vol} 35 / \mathrm{iss} 2 / 2>$, s.e.t.17.02.2020.

Bayraktar, Köksal (1972) Hekimin Tedavi Nedeniyle Cezai Sorumluluğu, İstanbul, İstanbul Üniversitesi Yayınları No. 768, Hukuk Fakültesi Yayınları No. 391, Sermet Matbaası.

Bulut, Nihat (2008) “Eski Yunan'dan Aydınlanma Çağı’na İnsan Onuru Kavramının Gelişimine Bir Bakı”, Erzincan Üniversitesi Hukuk Fakültesi, C.XII, Sa.3-4, ss.1-12.

Case of Association X . V/The United Kingdom, Application No. 7154/75, Judgment 12/07/1978, Para. $<$ http://hudoc.echr.coe.int/eng\#\{"appno":["7154/75"]\} , $\quad$ s.e.t.17.02. 2020.

Case Of Calvelli v. Italy, Application No. 32967/96, Judgment 17/02/2002 $<$ https://hudoc.echr.coe.int/eng\#\{"fulltext":["ciglio"],"documentcollectio nid2":["GRANDCHAMBER","CHAMBER"],"itemid":["001-60329"]\}>, s.e.t.17.02.2020. 
Case of Cyprus v. Turkey, Application No. 25781/94, Judgment 10/05/2001, Para. No.

219 , $<$ http://hudoc.echr.coe.int/eng\#\{"display":["0"],"languageisocode":["TU R"],"appno":[" 25781/94"],"documentcollectionid2":["GRANDCHAMBER"]\}>, s.e.t. 17.02.2020.

Case of Juhnke v. Turkey, Application No. 52515/99, Judgment 13/08/2008, $<$ http://hudoc.echr.coe.int/eng\#\{"languageisocode":["TUR"],"appno":["5 2515/99"],"documentcollectionid2":["CHAMBER"]\}>, s.e.t.09.10.2018.

Case of Osman v. The United Kingdom, Application No. 87/1997/871/1083, Judgment 28/10/1998, Para. No. $<$ https://hudoc.echr.coe.int/eng\#\{\%22fulltext\%22:[\%22 osman\%22],\%22itemid\%22:[\%22001-58257\%22]\}>, s.e.t.17.02.2020.

Case of Oyal v. Turkey, Application No. 4864/05, Judgment 23/06/2010, Para. No. $6,7,8,9,10,72$, $<$ http://hudoc.echr.coe.int/eng\#\{"fulltext":["4864/05"],"display":["0"],"ite mid":

["001-162088"]\}>, s.e.t.17.02.2020.

Case of Powell v. The United Kingdom, Application No. 45305/99, Judgment 04/05/2000, $<$ http://hudoc.echr.coe.int/eng\#\{"fulltext":["powell"],"itemid":["0015215"]\}>, s.e.t.17.02.2020.

Case of Tarariyeva v. Russia, Application No. 4353/03, Judgment 14/12/2006, Para. $\quad$ No. 74, <https://www.legal-tools.org/doc/a6ab2f/pdf/>, s.e.t.17.02.2020.

Çelik, Aziz (2005) “Avrupa Sosyal Şartı ve Türkiye’nin Çekinceleri” Türk-İş, Sa. 366, ss. 91-99.

Çınar, Ülkü (2003) “Sağlık Hukuku” (Doktora), İstanbul Üniversitesi Adli Tıp Enstitüsü.

Danışman, Ahmet (1991) Ceza Hukuku Açısından Özel Hayatın Korunması, 1. Baskı, Konya, Selçuk Üniversitesi.

Demir, Fevzi (2017) Anayasa Hukuku, 10. Baskı, İzmir, Birleşik. 
Demir, Fevzi/Bakıcı, Zeynel/Çınarlı, Serkan, (2011) Etkin Demokratik Hukuk Devleti, 1. Baskı, Ankara, Orion.

Demir, Mehmet (2006) Sağlık ve Tip Hukuku Mevzuatı ve Uluslararası Kaynaklar, 1. Baskı, Ankara, Turhan.

Demir, Simge (2018) Kamu Görevlisi Hekimlerin Tibbi Müdahaleden Kaynaklanan Sorumluluğu, 1. Baskı, Ankara, Seçkin.

Demirbaş, Timur (2016) İşkence Suçu, 2. Baskı, Ankara, Seçkin.

Demren Dönmez, Burcu (2012) “Ayrımcılık Suçu”, Türkiye Barolar Birliği, Sa. 102, ss. 9-58.

Doğru, Osman (2010) Anayasa ile Karşılaştırmalı İnsan Hakları Avrupa Sözleşmesi ve Mahkeme İçtüzüğü, 1. Baskı, İstanbul, On İki Levha.

Döner, Ayhan (2003) İnsan Haklarının Korunması ve Avrupa Sistemi, 1. Baskı, Ankara, Seçkin.

Duman, İlker Hasan (1997) Sosyal Devlet, 1. Baskı, İstanbul, İnkılap.

Dural, Mustafa/Öğüz, Tufan (2010) Türk Özel Hukuku Cilt II Kişiler Hukuku, İstanbul, Filiz.

Durmuş, Ayhan/Durmuş, Merve Nur (2019) “Sağlık Bakanlığı Teşkilat Yapısı”, Uluslararası Sağlık Yönetimi ve Stratejileri Araştırma, Sa. 2, C. 5, No. 2, ss. 216-229.

Duvefelt, Sabine/Sjölander, Carolina (2009) "Multiple Discrimination", Örebro University Department of Behavioural, Social and Legal Sciences, Legal Science Programme with International Approach, 240 ECTS Bachelor Thesis of 15 ECTS, Örebro, <http://oru.divaportal.org/smash/record.jsf?pid=diva2\%3A135637\&dswid=0.81007867 $64248513>$, s.e.t.17. 02.2020 .

Erdem, Mustafa Ruhan (2001) Ceza Muhakemesinde Organize Suçlulukla Mücadelede Gizli Soruşturma Tedbirleri, 1. Baskı, Ankara, Seçkin.

Erdoğan, Gülnur (2008) “Avrupa Sosyal Şartı ve Gözden Geçirilmiş Avrupa Sosyal Şartı”, Türkiye Barolar Birliği, Sa. 77. 
Erdoğan, Mustafa (2001) Türkiye'de Anayasalar ve Siyaset, 3. Baskı, Ankara, Liberte.

Ertan, İzzet Mert (2012) Uluslararası Boyutlarıyla Sağlık Hakkı, 1. Baskı, İstanbul, Legal.

Gemalmaz, Mehmet Semih (2011) Ulusalüstü İnsan Hakları Hukuku Belgeleri, Cilt II, 1. Baskı, İstanbul, Legal.

Gökcan, Hasan Tahsin (2017) Tibbi Müdahaleden Doğan Hukuki ve Cezai Sorumluluk, 3. Baskı, Ankara, Seçkin.

Gören, Zafer (1993) Temel Hak Genel Teorisi, 2. Baskı, İzmir, Cumhuriyet.

Göze, Ayferi (2005) Liberal Marxiste Faşist ve Sosyal Devlet, 4. Baskı, İstanbul, Beta.

Göze, Ayferi (2015) Siyasal Düşünceler ve Yönetimler, 15. Baskı, İstanbul, Beta. Gözler, Kemal (2012) Kısa Anayasa Hukuku, 7. Baskı, Bursa, Ekin.

Gül, İdil Işıl/Karan, Ulaş (2011) Ayrımcılık Yasağı Eğitim Rehberi, 1. Baskı, İstanbul, İstanbul Bilgi Üniversitesi.

Günaydın, Davuthan (2011) "Sağlık Hizmetlerinde Küresel Reform Yaklaşımları”, Sosyal Siyaset Konferansları, Sa. 60, C. 0, ss. 323-365.

Güntürk, Mümin Serdar (2012) Özel Hayatın Gizliliğinin Korunması, 1. Baskı, Ankara, Seçkin.

Gürbüz, Nagehan (2014) Biyotıp Hukukunda İnsan Onuru, 1. Baskı, İstanbul, On İki Levha.

Heinzmann, Richard (2010) "İnsan ve İnsan Onuru-Toplumsal Yaşam İçin Etik ve Ahlak", ss. 53-65, $<$ http://www.konrad.org.tr/Islam\%20tr\%202006/07heinzmanTR.pdf>, s.e.t.

17.02.2020.

Huber, Ernst Rudolf (1970) “Modern Endüstri Toplumunda Hukuk Devleti ve Sosyal Devlet”, Ankara Üniversitesi Hukuk Fakültesi, C. XXVII, Sa. 3-4, ss. 27-51, (Çeviren: Ansay, Tuğrul).

İnceoğlu, Sibel (2001) “Türk Anayasa Mahkemesi ve Avrupa İnsan Hakları Mahkemesi Kararlarında Eşitlik İlkesi ve Ayrımcılık Yasağın 
Çerçevesinde Af, Şartla Salıverme, Dava ve Cezaların Ertelenmesi”, Anayasa Yargis1, C. 18, ss. 41-70.

İnceoğlu, Sibel/Boyar, Oya/Karan, Ulaş/Akbulut, Olgun/Arslan Öncü, Gülay/Tokuzlu, Lami Bertan (2013) İnsan Hakları Avrupa Sözleşmesi ve Anayasa, 3. Baskı, İstanbul, Beta.

Kaboğlu, İbrahim Ö., "Hukukun Genel İlkeleri ve Anayasa Yargısı", $<$ http://www.anayasa.gov.tr/files/pdf/anayasa_yargisi/anyarg8/kaboglu. pdf $>$, s.e.t.17.02.2020.

Kaboğlu, İbrahim Ö. (1990) “Türkiye'de Hukuk Devletinin Gelişimi”, İnsan Hakları Yıllığı, Sa. 12/1.

Kalemoğlu, Murat, (2005) “Acil Serviste Hekim Sorumluluğu”, Türkiye Klinikleri Tip Bilimleri, C. 25, Sa. 6, ss. 824-82.

Kapani, Münci (2013) Kamu Hürriyetleri, 7. Baskı, Ankara, Yetkin.

Karahasan, Mustafa Reşit (1976) Tazminat Davaları, Yenilenmiş ve Genişletilmiş Baskı, İstanbul, İstanbul Matbaası.

Karan, Ulaş (2007) “Türk Hukukunda Ayrımcılık Yasağı ve Türk Ceza Kanunu'nun 122. Maddesinin Uygulanabilirliği”, Türkiye Barolar Birliği, Sa. 73, ss. 146-173.

Karan, Ulaş, Eşitlik İlkesi ve Ayrımcılık Yasağı: Hukuksal Çerçeve, ss. 1-13, $<$ http://secbir.org/images/haber/2011/01/12-ulas-karan.pdf>, s.e.t.17.02.2020.

Katikireddi, Vittal, (2004) "New Regular Report Will Monitor Global Health Issues”, BMJ, 328, 728.

Kızılarslan, Hakan (2007) Ceza Muhakemesi, Adli Tip, Adli Bilimlerde Vücudun Muayenesi ve Örnek Alma Doktrin ve Uygulama, 1. Baskı, Ankara, Çetin Veb-Ofset A.Ş..

Kızılkaya Doğru, Ezgi (2016) Tıbbi Müdahaleler Karşısında İnsan Hakları, Açlık Grevi ve AIDS/HIV, 1. Baskı, Ankara, Adalet.

Koca, Mahmut/Üzülmez, İlhan (2015) Türk Ceza Hukuku Özel Hükümler, 2. Baskı, Ankara, Adalet. 
Koç, Seda (2007) "İnsan Hakları Sözleşmesinin Tıbbi Karar Alma Sürecine Etkileri (1998)", Özel Yaşam, Medya ve Ceza Hukuku, 1. Baskı, Ankara, Seçkin.

Korkusuz, M. Refik (1998) Uluslararası Belgelerde ve Türk Anayasası'nda Temel Hak ve Özgürlükler, 1. Baskı, İstanbul, Örnek.

Köroğlu, Ertuğrul (1984) Sağlık Personelini İlgilendiren Hukuk Kuralları Sağlık Mevzuatı, 1. Baskı, Ankara, Hacettepe Yayın Birliği\&Yargıçoğlu.

Madenoğlu Kıvanç, Meral (2015) “Evrensel Sağlık Bildirgeleri ve Türkiye’de Sağlık Reformları”, Sağlık ve Hemşirelik Yönetim, C. 2, Sa. 3, ss. 162-166.

Mcdougal, S. Myres/Chen, Lung-chu/Lasswell, Harold D., (1977) "Human Rights in World Public Order: Human Rights in Comprehensive Context", Yale Law School Faculty Scholarship Series, Paper 2665, Yale, $<$ http://digitalcommons.law.yale.edu/fss_papers/2665>, s.e.t.17.02.2020.

Mumcu, Ahmet/Küzeci, Elif (2015) İnsan Hakları ve Kamu Özgürlükleri, 7. Baskı, Ankara, Turhan.

Nuhoğlu, Ayşe (1999) “İşkence Yasağı ve İşkence Suçu”, Prof.Dr.Sahir Erman’a Armağan, İstanbul Üniversitesi Hukuk Fakültesi Eğitim Öğretim ve Yardımlaşma Vakfı Yayın No. 8, İstanbul.

Oder, Bertil Emrah (2008) "Devletin Olumlu Edimine Gerektiren Sosyal Hakların Anayasal Düzeyde Korunması ve Yargisal Tutumlar", Galatasaray Üniversitesi Hukuk Fakültesi, C. 1, ss. 199-231.

Önok, Murat (2006) Uluslararası Boyutuyla İşkence Suçu, 1. Baskı, Ankara, Seçkin.

Özay, İl Han (2002) Günışığında Yönetim, İstanbul, Alfa.

Özbudun, Ergun (2016) Türk Anayasa Hukuku, 16. Bask1, Ankara, Yetkin.

Özek, Çetin (1978) Türk Basın Hukuku, 1. Baskı, İstanbul, İstanbul Üniversitesi.

Özsunay, Ergun (1982) Gerçek Kişilerin Hukuki Durumu, 5. Baskı, İstanbul, Der. 
Öztekin Ali (2015) "Devletin Asli Ve Sürekli Görevleri (Temel Kamu Hizmetleri) Ve Özellikleri”, Akdeniz İktisadi ve İdari Bilimler Fakültesi, Sa.30, ss.10-19.

Öztürk, Bahri (2003) "Yaşama Hakkı Ve İşkence Yasağı (Yasak Sorgu Metodları)", İstanbul Kültür Üniversitesi Hukuk Fakültesi, C. 2, Sa. 1-2, ss. 39-80.

Polatcan, İsmet (1989) Türkiye Cumhuriyeti Anayasası, Gerekçeler, Anayasa Mahkemesi Kararları, Bilimsel Görüşler, 1. Baskı, İstanbul, Bayrak.

Sabuncu, Yavuz (2007) Anayasaya Giriş Ek: 1982 Anayasası, 13. Baskı, Ankara, İmaj.

Salihpaşaoğlu, Yaşar, (2013) "Özel Hayatın Kapsamı: Avrupa İnsan Hakları Mahkemesi İçtihatları Işı̆̆ında Bir Değerlendirme”, Gazi Üniversitesi Hukuk Fakültesi, C. XVII, Sa. 3, ss. 227-266.

Sayek, Füsun (1998) Sağlıkla İlgili Uluslararası Belgeler, 1. Baskı, Ankara, Türk Tabipleri Birliği.

Serozan, Rona (2013) Marx/Engels Devlet ve Hukuk Üzerine, 3. Bask1, İstanbul, Çağdaş Hukukçular Derneği.

Seymen Çakar, Ayşen (2013) "Hukuki Bir Kavram Olarak İnsan Onuru", Umut Vakfı Araştırma Merkezi 3. Hukukun Gençleri Sempozyumu, Antalya, ss. 1-8.

Shestack, Jerome J. (2006) "İnsan Haklarının Felsefi Temelleri", Liberal Düşünce, C. 11, No. 43, ss. 87-119.

Soysal, Mümtaz (1997) 100 Soruda Anayasanın Anlamı, 11. Baskı, İstanbul, Gerçek.

Şen, Ersan (1996) Devlet ve Kitle İletişim Araçları Karşısında Özel Hayatın Gizliliği ve Korunması, İstanbul, Kazanc1.

Şenel, Alaeddin (1969) “Eşitlik Kavramı ve Tarihsel Gelişimi”, Yavuz Abadan’a Armağan, Ankara, Ankara Üniversitesi Sosyal Bilgiler Fakültesi.

Şenel, Alaeddin (1970) Eski Yunanda Eşitlik ve Eşitsizlik Üstüne, 1. Baskı, Ankara, Sevinç. 
Şimşek, Oğuz (1999) “Anayasa Hukukunda İnsan Onuru Kavramı ve Korunması" (Doktora), Dokuz Eylül Üniversitesi Sosyal Bilimler Enstitüsü.

T.C. Adalet Bakanlığı Ceza İşleri Genel Müdürlüğü, 158 Nolu Genelge, Sa. 19120602-010-06-02-0114-2015-403, Y.T.20.02.2015.

T.C. Başbakanlık Personel ve Prensipler Genel Müdürlüğü, 1997/73 Nolu Genelge, Sa. B.02.0.PRG.0.12-383-27961, Y.T.03.12.1997.

T.C. Başbakanlık Personel ve Prensipler Genel Müdürlüğ̈̈, 1999/39 Nolu Genelge, Sa. B.02.0.PPG.0.12-320-08689, Y.T.25.06.1999.

Tanilli, Server (2007) Devlet ve Demokrasi: Anayasa Hukukuna Giriş, 4. Baskı, İstanbul, Alkım.

Tanör, Bülent (2010) Osmanlı-Türk Anayasal Gelişmeleri, 19. Baskı, İstanbul, Yap1 Kredi.

Tanör, Bülent/Yüzbaşığlu, Necmi (2016) 1982 Anayasasına Göre Türk Anayasa Hukuku, İstanbul, Beta.

TBMM, Avrupa Sosyal Şartı (Değiştirilmiş Şekli); <https://www.tbmm.gov.tr/ komisyon/kefe/docs/sosyalsart.pdf>, s.e.t.17.02.2020.

Temiz, Özgür (2013) “Türk Hukukunda Sağlı Hakkı ve Bir Kamu Hizmeti Olarak Sağlık” (Doktora), Ankara Üniversitesi Sosyal Bilimler Enstitüsü.

Temiz, Özgür (2014) “Türk Hukukunda Bir Temel Hak Olarak Sağlık Hakk»”, Ankara Üniversitesi SBF, C. 69, Sa. 1, ss. 165-188.

Tezcan, Durmuş/Erdem, Mustafa Ruhan/Önok, Murat (2016) Teorik ve Pratik Ceza Özel Hukuku, 13. Baskı, Ankara, Seçkin.

The Bangkok Charter for Health Promotion in a Globalized World, Health Promot, Int. 2006 21, $<$ http://www.who.int/healthpromotion/conferences/6gchp/hpr_050829 _\%20BCHP.pdf?ua=1>, s.e.t.17.02.2020.

Toroslu, Nevzat (1970) Cürümlerin Tasnifi Bakımından Suçun Hukuki Konusu, Ankara, Sevinç.

Turner, Bryan (2013) Eşitlik, 4. Baskı, Dost, Ankara. 
Uyar, Lema (2006) Birleşmiş Milletler'de İnsan Hakları Yorumları İnsan Hakları Komitesi ve Ekonomik, Sosyal ve Kültürel Haklar Komitesi, 1981-2006, 1. Bask1, İstanbul, İstanbul Bilgi Üniversitesi Yayınları.

Uygun, Oktay (2013) Kamu Hukuku İncelemeleri, 2. Baskı, İstanbul, On İki Levha.

Üzülmez, İlhan (2003) Türk Ceza Hukukunda İşkence Suçu, 1. Baskı, Ankara, Turhan.

WHO (1986) Ottawa Charter for Health Promotion First International Conference on Health Promotion Otawa, Ottawa, $<$ http://www.who.int/healthpromotion/conferences/ previous/ottawa/en/>, s.e.t.17.02.2020.

WHO Secretariat Background Document fort he 6th Global Conference on Health Promotion in Bangkok, "Global Health Promotion Scaling up for 2015- A brief review of major impacts and developments over the past 20 years and challenges for 2015", Thailand, $<$ http://www.who.int/healthpromotion/conferences/6gchp/hpr_confere nce_background.pdf $>$, s.e.t.17.02.2020.

Yardım, Nazan/Gögen, Sibel/Mollahaliloğlu, Salih (2009) "Sağlı̆̆ın Geliştirilmesi; Dünyada ve Türkiye'de Mevcut Durum”, İstanbul Tip Fakültesi, İstanbul, C. 72, Sa. 1, ss. 29-35.

Yıldız, Hicran/Turan, Mustafa (2010) “Küreselleşme ve Sağlık”, Uludağ Üniversitesi Tıp Fakültesi, C. 36, Sa. 1, ss. 39-41.

Yılmaztürk, Aysun (2013) “Türkiye’de Sağlık Reformlarının Tarihsel Gelişimi ve Sağlıkta Dönüşüm Programı'nın Küresel Niteliğinin Değerlendirilmesi”, Sosyal Bilimler Araştırmaları, Sa. I, C. 8, ss. 176-188.

Yüzbaşığlu, Necmi (1993) Türk Anayasa Yargısında Anayasallık Bloku, 1. Baskı, İstanbul, İstanbul Üniversitesi Hukuk Fakültesi.

Zafer, Hamide (2010) Özel Hayatın Gizli Alanının Ceza Hukukuyla Korunması, 1. Baskı, İstanbul, Beta. 
http://kararlaryeni.anayasa.gov.tr/Karar/Content/0c083aal-96f0-4e67-8f67-

$6 \mathrm{~d} 74 \mathrm{a} 867 \mathrm{fa} 56$ ? excludeGerekce $=$ False $\&$ wordsOnly $=$ False, s.e.t.17.02.2020.

http://kararlaryeni.anayasa.gov.tr/Karar/Content/837e7b82-f11e-4ebc-b508da594476a15c?excludeGerekce=False\&wordsOnly=False, s.e.t.17.02.2020.

http://kararlaryeni.anayasa.gov.tr/Karar/Content/eb2d4895-a40f-44ee-8492-

831a8d126401 ?excludeGerekce=False\&wordsOnly=False,

s.e.t.17.02.2020.

http://www.kazanci.com/kho2/ibb/files/dsp.php?fn=10d-2005-

8407.htm\&kw=`E.2005/8407`\#fm, s.e.t.17.02.2020.

https://www.wma.net/what-we-do/medical-ethics/declaration-of-geneva/,

s.e.t.17.02.2020.

https://www.wma.net/what-we-do/medical-ethics/declaration-of-

helsinki/,s.e.t.17.02.2020.

https://www.wma.net/what-we-do/medical-ethics/declaration-of-

taipei/,s.e.t.17.02.2020.

https://www.wma.net/what-we-do/medical-ethics/declaration-of-tokyo/, s.e.t.17.02.2020. 